\title{
Effects of Exotic Plantation Expansion and Management Intervention on Woody Plant Species Diversity, Regeneration and Soil Seed Bank in Tarmaber District, Ethiopia
}

Melese Bekele Nigussie ( $\nabla$ mel21bekele@gmail.com )

Amhara Agricultural Research Institute, Debere Birhan Agricultural Research Center Forestry Research Directorate

Dessie Assefa Assefa

Department of Natural Resource and Environmental Science, Bahir Dar University, Ethiopia Yohannis Gebremariam Gebremariam

Department of Forestry and Environmental Science, Gondar University, Ethiopia

Research

Keywords: Floristic diversity, Management intervention, Natural forest, Plantation forest, Soil seed bank

Posted Date: January 13th, 2021

DOl: https://doi.org/10.21203/rs.3.rs-143013/v1

License: (c) (1) This work is licensed under a Creative Commons Attribution 4.0 International License.

Read Full License 


\title{
Effects of Exotic Plantation Expansion and Management Intervention on Woody Plant Species Diversity, Regeneration and Soil Seed Bank in Tarmaber District, Ethiopia
}

\author{
Melese Bekele $^{1 *}$, Dessie Assefa ${ }^{2}$ and Yohannis Gebremariam ${ }^{3}$ \\ 1. Amhara Agriculture Research Institute, Debre Birhan Agriculture Research Center, Ethiopia \\ 2. Department of Natural Resource and Environmental Science, Bahirdar University, Ethiopia \\ 3. Department of Forestry and Environmental Science, Gondar University, Ethiopia \\ *Corresponding Author: mel21bekele@gmail.com
}

\begin{abstract}
This study was carried out in Tarmaber district north shewa zone Ethiopia to determine the effect of plantation forest with management intervention on woody plant species diversity, regeneration and soil seed bank species composition in five different forest types, which are adjacent natural forest, managed Cupressus lusitanica, unmanaged C. lusitanica, managed Eucalyptus globules and not managed E. globules plantation forests. A total of 75 circular sample plots of $314 \mathrm{~m}^{2}$ were established along a transect lines. Soil seed bank analysis was done from soil samples collected in each of the plots ( 225 samples) to examine the similarity between the soil seed bank and aboveground flora. Different diversity index and ANOVA was used in SPSS software for analysis. The result showed that a total of 51 woody plant species was recorded in adjacent natural forest (41), managed $C$. lusitanica (27), not managed $C$. lusitanica (9), managed $E$. globules (22) and not managed E. globules (13) species. Regeneration of seedlings were 3538, 5567, 707, 1462 and 2524 mean stems ha $^{-1}$ for natural forest, managed C. lusitanica, not managed C. lusitanica, managed E. globules and not managed E. globules respectively. Unmanaged $C$. lusitanica plantations had significantly lower densities of mature tree stems ha ${ }^{-1}$ as compared to managed $C$. lusitanica, managed E. globules and adjacent natural forest $(\mathrm{F}=14.03$, $\mathrm{p}<0.05)$. Similarly in terms of sapling density $\mathrm{ha}^{-1}$ unmanaged $C$. lusitanica was significantly lower from other forest types $(\mathrm{F}=7.37, \mathrm{p}<0.05)$. However managed C. lusitanica had significantly higher seedling regeneration (stem density $\mathrm{ha}^{-1}$ ) than other plantation and adjacent natural forests $(\mathrm{F}=16.11, \mathrm{p}<0.05)$. Generally mean stem densities including tree, sapling and
\end{abstract}


seedling of woody species among different forest types managed $C$. lusitanica was significantly higher among different forest types $(F=13.01, \mathrm{p}<0.05)$. From the soil seed bank a total of 22 plant species (20 native and 2 exotic) species were recovered. In different forest types the number of species recorded was in adjacent natural forest (19), managed C. lusitanica (11), unmanaged C. lusitanica (4), managed E. globules (7) and unmanaged E. globules (5). The similarity of the oil seed bank was more or less similar to the above ground flora with maximum Sorenson's similarity values of 0.633 . Generally with appropriate management intervention undergrowth vegetation and soil seed bank status in plantation forest had good species composition and diversity.

Key words: Floristic diversity, Management intervention, Natural forest, Plantation forest, Soil seed bank 


\section{INTRODUCTION}

To overcome the shortage of wood caused by extensive deforestation, plantation forest with exotic tree species like Eucalyptus, Cupressus and pinus were started in Ethiopia since 18941895 (Shiferaw \& Jindrich, 2012) and are the most successfully introduced and widely distributed plantation throughout the country (Markus, 2012). The reason to be widespread is attributed to their fast growth, and their adaptability to a wide range of site conditions (Abrham $e t$ al., 2011).

Even though plantations have many economic and environmental benefits, intensive monoculture exotic plantations are widely viewed negatively mainly in relation to biological diversity conservation, and undergrowth regenerations (Carnus et al., 2006). For example, scientific and community stake holders argued that Eucalyptus species do not provide valuable organic matter, deplete soil nutrients, pump up water resources used for agricultural crops, suppress ground vegetation by secretion of allopathic chemicals, and unsuitable soil erosion control because of the less undergrowth vegetation (Becerra et al., 2018; Sekaleli, 2012; Tilashwork, 2009).

Although it has criticism on its negative impact for environment, Eucalyptus, Cupressus, and Pinus are the most commonly used species for plantation purpose throughout the world (Sean $\&$ Robert, 2003).

A study on the tropical forest plantations indicated that they may rarely promote the recruitment, establishment and succession of native woody species by fostering ecosystems (Parrota, 1992). Different studies on plantations of Eucalyptus globulus, Eucalyptus saligna, Eucalyptus grandis, Pinus patula, Pinus radiata, Cupressus lusitanica and Grevillea robusta established in high rainfall and relatively high altitudes of Ethiopia also proved a catalytic role of these monoculture plantation with regard to habitat re-colonization by native woody plants (Shiferaw \& Jindrich, 2012; Feyera \& Demel, 2003).

Management intervention on exotic plantation to foster the undergrowth vegetation and the upper canopy to make productive the harvestable yield and substitute regeneration is important (Gilman et al., 2016). Because, the different management interventions avoid competition of light, nutrient and moisture the upper canopy trees and undergrowth vegetation (Williams, 2015).

Most farmers and expert's dealing the negative impact on expansion of exotic plantation forests concerning ecological and environmental issues in the study area. However, studies on the regeneration of native woody plants under plantation forest with management intervention and feelings of local people about exotic plantation forest in ecological dilemma have limited 
information in the study area. The general aim of this study is to evaluate the potential effects of exotic plantation with management intervention on the natural regeneration of woody plants and the insight of local people about exotic plantation expansion interaction to the environment in order to synthesize truth information and to verify the dilemma about plantation forest in the highland part of North Shewa Zone, Ethiopia.

\section{Statement of the Problem}

This specific study was conducted in the highland of North Shewa zone Tarmaber district under Eucalyptus globulus plantation with and without enrichment planting by indigenous tree species and Cupressus lusitanica plantation with and without pruning management intervention under the concession of Amhera Forest Enterprise (Amhera Forest Enterprise (AFE), 2017). Different authors observed exotic plantation in different angles: in one group debated the negative impact on biological diversity conservation, native woody species regeneration and composition, animal fodder reduction due to allopathic chemicals (Sean \& Robert, 2003; Carnus et al., 2006). On the other side stated the positive effect of plantation forest on understory regeneration, diversity and composition, such as Hundera (2011) in Belete forest, Shiferaw \& Jindrich (2012) in Gibie valley; Feyera \& Demel (2003) in Menagesha forest, and Tadele \& Fetene (2013) in MunessaShashemene forest. In addition, monoculture Cupressus lusitanica plantations are facilitating the regeneration of woody plants in wider spacing (Shiferaw et al., 2015). Generally the above authors indicated the significant role of monoculture exotic tree species for encouragement of native biodiversity by enhancing the subsequent succession processes with appropriate management interventions like spacing, seed throwing, pollarding and thinning to reduce competition among understory and overstores vegetation. But due to the belief on agricultural land competition and ecological impacts like hindering native biodiversity regeneration and composition; nursery sites stop producing exotic plantation seedlings and restricted planting on their farm lands and farm land boundaries, except enterprise and private nursery sites (Tarmaber Woreda Agricultural Office, 2018). Therefore there is limited information in a logical investigation about the management intervention effect on woody species regeneration, composition, diversity, vegetation structure, soil seed bank under the canopy of plantation forest in the study area comparing to the adjacent natural forest and unmanaged plantation forests. Therefore, this study would fill the information gap on the effect of management interventions on species composition, regeneration and soil seed bank status and its role for regeneration. 


\section{Objectives}

* To assess the diversity of native woody plant species in the Eucalyptus plantation, Cupressus plantations and adjacent natural forest.

* To assess the effect of management intervention on understory woody vegetation regeneration and diversity composition.

* To evaluate the role of soil seed bank for the regeneration and composition of woody plant species in the plantation and adjacent natural forests.

* To study the soil seed bank (vertical distribution and density) in the plantation forest and adjacent natural forest.

\section{MATERIALS AND METHODS}

\section{The Study Area Description}

The reason behind the selection of Tarmaber district was the existence of huge plantation forests on the study area both state forest and private woodlot plantation as well as an adjacent natural forest in similar agro-ecology. The forest is currently owned by Amhara Forest Enterprise. In Tarmaber plantation forest different management intervention was involved by the government and the community before Amhara Forest Enterprise established to produce quality timber and fuelwood collection from the part of branches. The other management interventions involved was enrichment planting on left lands under the plantation forest stand using different indigenous tree species. Generally this research was conducted under five different forest types such as managed Cupressus lusitanica (pruning management involved), unmanaged Cupressus lusitanica (no pruning management involved), managed Eucalyptus globules (enrichment planting involved by different indigenous tree species like Juniperus procera), not managed Eucalyptus globules ( no enrichment planting involved by indigenous tree species) and adjacent natural forests. 


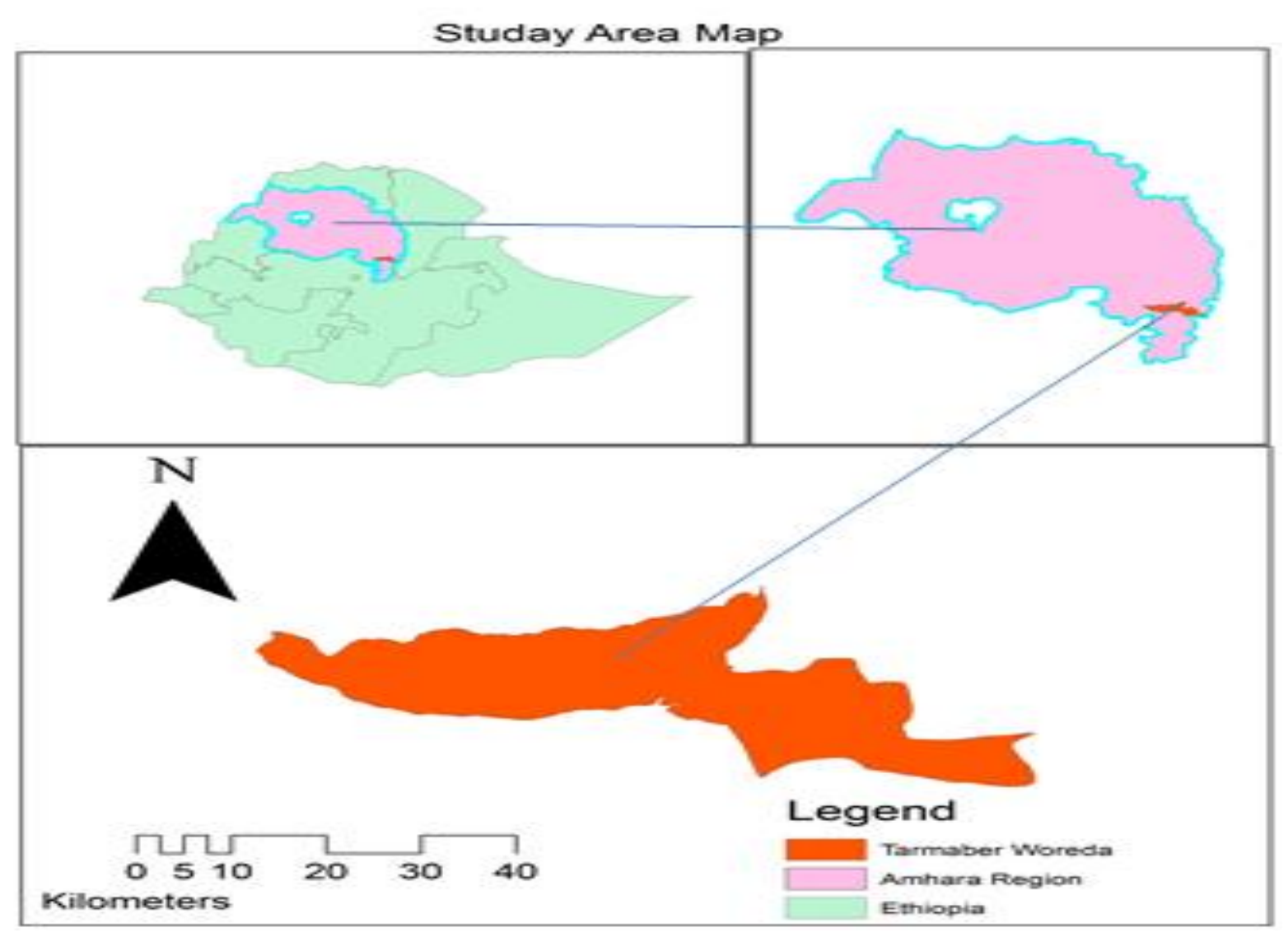

Figure 1: Map of Study Area

\section{Location, Topography, Soil and Population}

According to Figure (1) Tarmaber plantation forest is found in Tarmaber district North Shewa Zone of Amhara region, Ethiopia and it is geographically located between latitude $9^{\circ} 50^{\prime} 56.6^{\prime \prime} \mathrm{N}$ and longitude $39^{\circ} 43^{\prime} 56.4^{\prime \prime}$ E. The population of the woreda is 78950 of which 39,852 are male and the rest 39,098 are female including urban and rural dwellers (Central Statistics Agency, 2007). The topography is dominated by a chain of hills and rouged mountains; thereby $15.3 \%$ of the woreda is mountainous, $32.7 \%$ is plain lands, $6.3 \%$ valleys and $45.7 \%$ are rugged types (Mulugeta, 2017). Soil type in Tarmaber woreda mostly classified as verity soil (Tarmaber Woreda Agricultural Office (TWAO), 2018; Ethiopia Impact Assessment Report, 2011).

\section{Agro-ecology and Climate}

The study area agro-ecology is $17 \%$ lowland, 28\% semi-arid (Woinadega) and 55\% is highland (Dega) (TWAO, 2018). Its altitude is ranging from 1500 to 3300 meter above sea level. The 
monthly temperature of the study area ranges from $5.4^{\circ} \mathrm{C}$ to $19.9^{\circ} \mathrm{C}$ and mean monthly rain fall is about 9.1 - $433.6 \mathrm{~mm} /$ month (Figure 2).

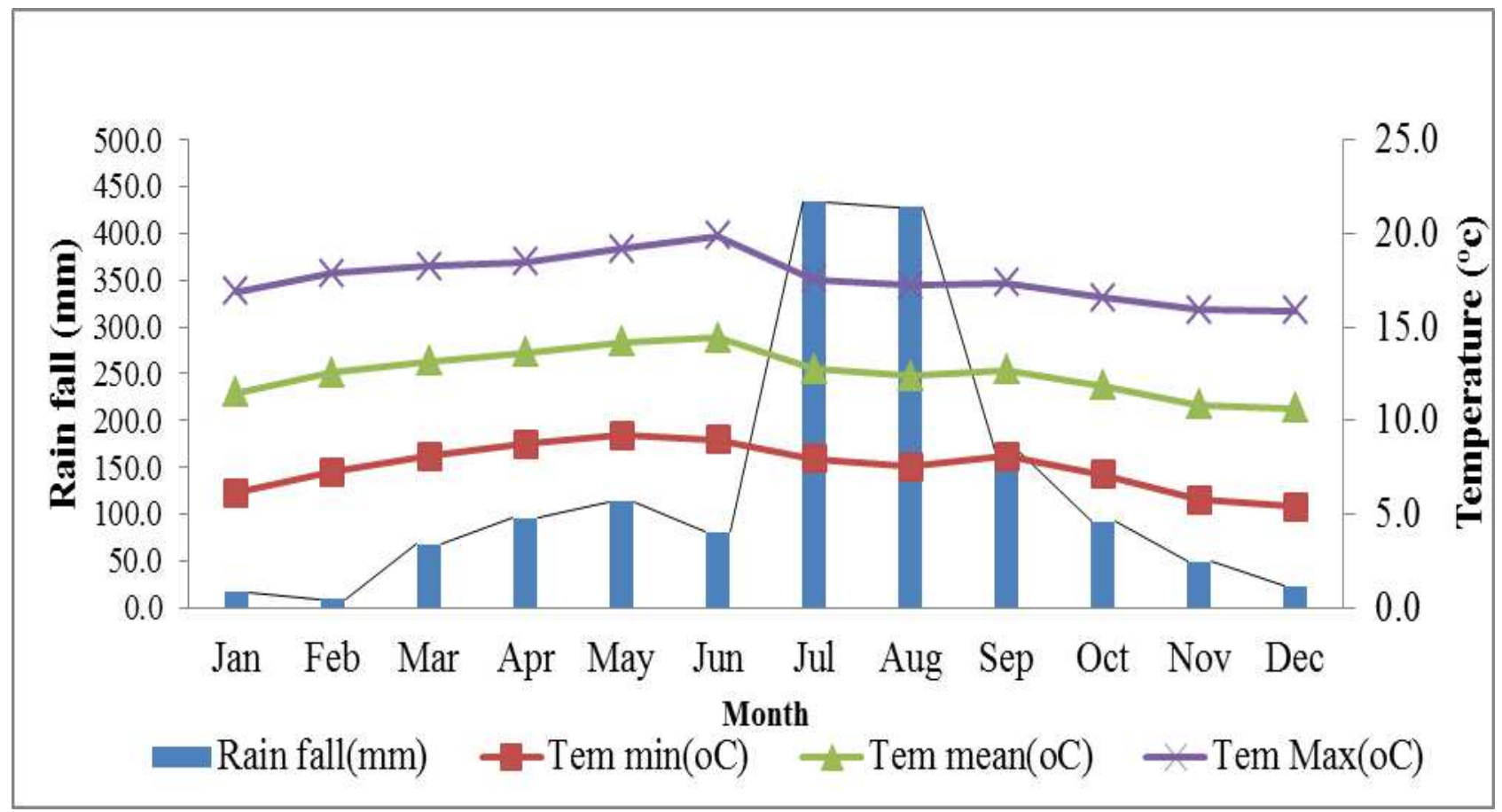

Figure 2: Long term average monthly rain fall, minimum, maximum and average temperature from 1994-2018 (Andit Tid metrological station), and $8 \mathrm{~km}$ far from the Tarmaber plantation forest)

\section{Vegetation type and Coverage in the Study Area}

Most of the areas have fairly poor vegetation cover especially on farming areas due to species diversification problem. Even though the study area have large plantation forest owned by Amhara Forest Enterprise and farmer's woodlots plantation forest like Eucalyptus globulus and Cupressus lusitanica. Whereas in different church forests, exclosures and ruminate Wof Washa forest, vegetation's like Juniperus procera, Olea europaea, Hagenia abyssinica, Dombeya torrida, Erica arborea and other important trees and shrub species has been existed. Generally the study Woreda has 41 ha woodland of high forest and 3224 ha of plantation forest (EIAR, 2011). 


\section{Description of the Plantation Forest}

Generally, plantation forests have been increased in the study area after the introduction of eucalyptus by fuel wood project since 1974 (Amogne, 2014). Currently $90 \%$ of the forest area is plantation forest while the rest $10 \%$ is covered by natural forest from the overall coverage of the forest (TWAO, 2018).

In the study area more forest areas covered by both eucalyptus and cupressus plantation forests. According to the Amhara Forest Enterprise, the land was previously cultivated land that was

owned by farmers. During Derg regime, the cultivated land was changed to forest land by planting eucalyptus and cupressus plantation and some part of the forest located on steep slopes (AFE, 2017).

\section{Description of the Natural Forest}

In the study area adjacent to the plantation forests different church and remnant natural forest was found and owned by the Abunearegaye church; which covers 15 ha (GPS coordinate point). And significant number of large and small mammals, birds, and plant species found in the boundary of wofe washa forest (Fisaha et al., 2013). The natural forest which is adjacent to the plantation forest were primarily dominated by trees and shrub species of Juniperus procera, Olea europaea subsp, Hagenia abyssinica, Dombeya torrida and Erica arborea in almost all parts of the forest and there is a high diversity. Trees/shrubs are regenerated in the gap that was created by aged tree dropping and harvesting inside the forest (Filled observation). During data collection, the church forest was selected due to similar in agro-ecology and soil type with that of plantation forests and accessibility for the study.

\section{Socio-economic Situation}

Most of the study area has plain and gently sloping lands that are used for cultivation whereas grazing lands and afforestation areas are found on the hillsides and marginal lands. Agriculture in the study area is rain-fed with a subsistence mixed farming system. Therefore, cultivated land, livestock's and plantation woodlot are the major assets for the community (TWOA, 2018). 


\section{Data Collection Method}

Quantitative approaches were used to address the objective of this research. The regeneration, diversity, density and structure of the forest data was collected using quantitative data collection method. Whereas the insight of local people about the trend of plantation expansion, impacts on environment was used qualitative data collection method.

\section{Vegetation Data Collection}

Vegetation inventory was carried out in five forest types, such as adjacent natural forest, managed and unmanaged Cupressus lusitanica and Eucalyptus globulus plantation forest. The vegetation data collection was conducted by applying a nested plot design using a line transects survey. All sample plots were located at least $10 \mathrm{~m}$ far from the forest boundary or roadside to avoid border effect (Yvette \& David, 2002). A circular plot was established at specified intervals along the transect line both in natural forest and managed and unmanaged plantation forests, based on using the distance between transect and sample plots for each forest types (Table 1). The first transect and sample plot was placed randomly at one side of each forest types, while the other sample plots laied at specified intervals from each other (Fikadu et al., 2014). The trees were measured in the $10 \mathrm{~m}$ radius, saplings in $5 \mathrm{~m}$ radius sampling plot and seedlings were measured in $3 \mathrm{~m}$ radius in a concentric circle (Shiferaw \& Jindrich, 2012). The plants was categorized as seedlings (height $<1.0 \mathrm{~m}$ and DBH $<2 \mathrm{~cm}$ ) saplings (height between 1 and $3 \mathrm{~m}$ and DBH $<10 \mathrm{~cm}$ ) and tree (height $>3 \mathrm{~m}$ and DBH $\geq 10 \mathrm{~cm}$ ) (Feyera et al., 2002; Feyera \& Demel, 2003; Ayanaw \& Gemedo, 2018). Height and diameter were measured by hypsometer and calliper respectively and the tree which had large diameter was measured by tape meter. Additionally, aspect, altitude and slop were recorded on each plot. A total of 75 sampling plots, 15 for each forest types were used along the study area and to increase precision and to make easy for analysis for each forest types equal sample plot was used. In each plot, all of the naturally regenerated woody species were identified and counted. Species identification and verification were done by referring the Flora of Ethiopia and Eritrea (Edwards et al.,2000) and natural database for Africa (NDA) on CD-ROM version 2.0, August 2011 (Ermias, 2011).

Table 1: Characteristics of the plantation and adjacent natural forest stands and sampling procedures at Tarmaber Amhara forest enterprise forests 


\begin{tabular}{|l|l|l|l|l|l|l|l|}
\hline Forest types & $\begin{array}{l}\text { Forest } \\
\text { area } \\
\text { (ha) }\end{array}$ & No. of & Sample & $\begin{array}{l}\text { No. } \\
\text { transects } \\
\text { plot in } \\
\text { sach } \\
\text { transect } \\
\text { plot }\end{array}$ & $\begin{array}{l}\text { Distance } \\
\text { between } \\
\text { transect }\end{array}$ & $\begin{array}{l}\text { Age of the } \\
\text { forest }\end{array}$ & $\begin{array}{l}\text { Distance } \\
\text { between } \\
\text { plot (m) }\end{array}$ \\
\hline Natural forest & 15 & 3 & 5 & 15 & $200 \mathrm{~m}$ & unknown & 50 \\
\hline Managed C. lusitanica & 38.5 & 3 & 5 & 15 & $400 \mathrm{~m}$ & Above $30 \mathrm{yr}$. & 100 \\
\hline Not managed C.lusitanica & 41 & 3 & 5 & 15 & $400 \mathrm{~m}$ & Above $30 \mathrm{yr}$. & 100 \\
\hline Managed E. globules & 23 & 3 & 5 & 15 & $200 \mathrm{~m}$ & Above $30 \mathrm{yr}$. & 100 \\
\hline Not managed E.globules & 69 & 3 & 5 & 15 & $400 \mathrm{~m}$ & Above $30 \mathrm{yr}$. & 150 \\
\hline Total & 186.5 & & & 75 & & & \\
\hline
\end{tabular}

Note: the configuration of the transect was based on the elevation of the area by classifying low $(2800 \mathrm{~m})$, medium $(3000 \mathrm{~m})$ and highest elevation $(3200 \mathrm{~m})$ relative to the land feature (Gillison \& Brewer, 2014). 


\section{Soil Sampling for Soil Seed Bank}

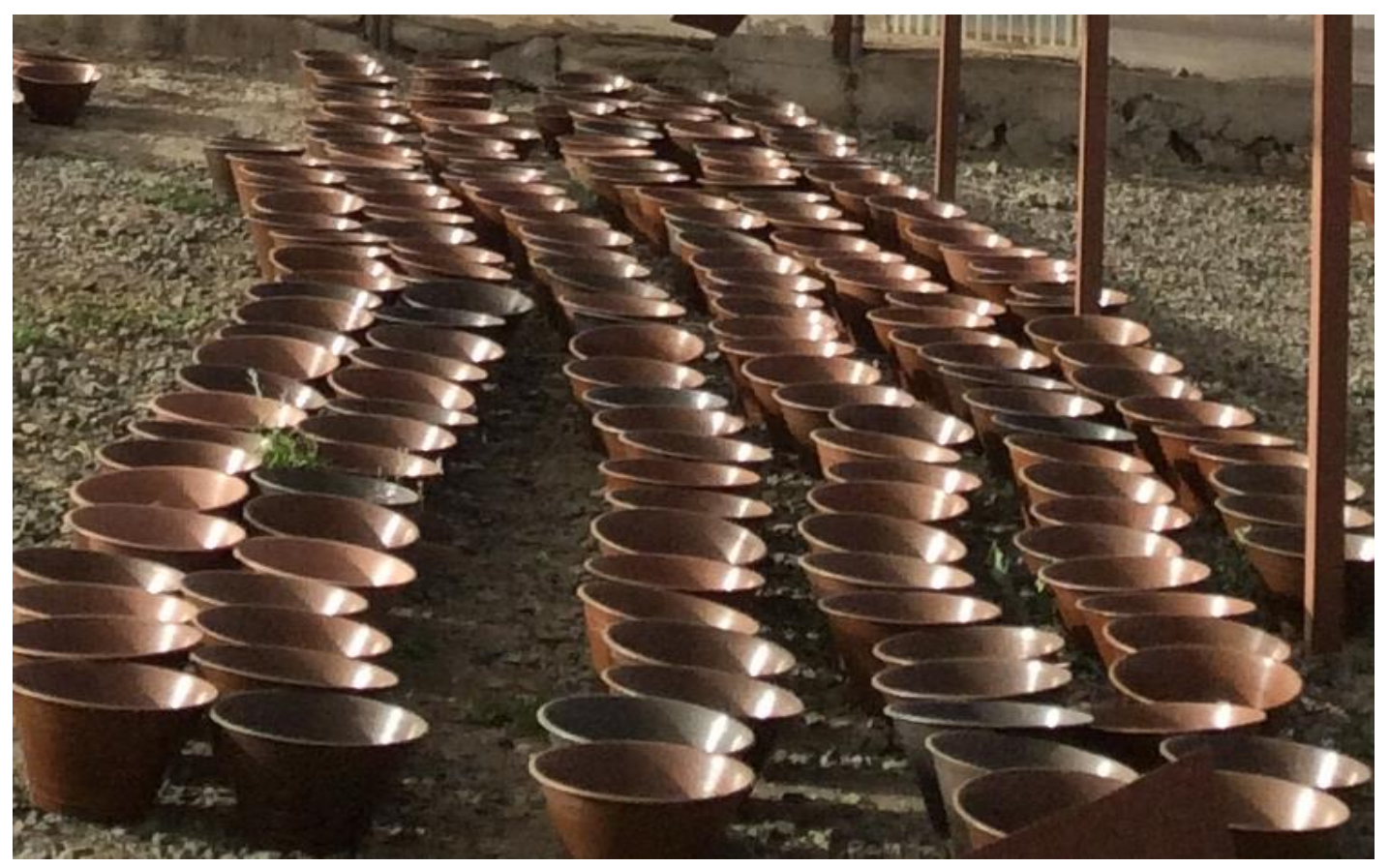

Figure 3: Growing seeds from the soil seed bank (inside the glass house)

In order to determine species composition, diversity, the vertical distribution as well as the similarity of aboveground flora in the soil seed bank soil samples was collected. A total of 225 soil samples were collected from the above surface layer and the soil depth of $0-5 \mathrm{~cm}$ and 5-10 $\mathrm{cm}$ both from the plantation forests and adjacent natural forests (Maranon, 1998). The soil seed bank samples were collected from the plots used for vegetation sampling. At the centre of each plot, a small plot of $20 \mathrm{~cm}$ x $20 \mathrm{~cm}\left(400 \mathrm{~cm}^{2}\right)$ was marked and collected soil seed bank sample from the three separate soil layers to investigate depth distribution of seeds in the soil. The soil samples were put into plastic bags separately and transported to Debre Birhan Agricultural Research Center for analysis. In cases of dissimilarity between soil and aboveground flora, soil depth was used to speculate the seed sources, whether recently dispersed seed or from the soil seed bank.

There are various methods involved in determining soil seed bank which has been adopted by many authors. These are a seedling emergence method, the sieving and floating methods (Eyob, 2006). The seedling emergence method is the most frequently used, and the more reliable method, in soil seed bank studies (Esmailzadeh et al., 2011; Gomaa, 2015). The emerging 
method was best compared to other methods because a seed which is not visible in the mixed soil samples by naked eyes can be observing the physical morphology of the seedlings (Wagner et al., 2003). Others identification methods are not commonly used and are time consuming, ineffective at finding small-seeded species and may overestimate the viable seed bank by including nonviable seeds (Savadogo et al.,2016; (Colin \& Lauren, 1996).

After transported the soil sample to the Debre Birhan Agricultural Research Center, all soil samples were sieved using a mesh size of $0.50 \mathrm{~mm}$ to recover seeds of woody species and to facilitate the germination process of the seeds, the soil samples were incubated in the glass house for four months (Figure 3) (Teketay, 2005). Then finally seedlings were identified, recorded and discarded once every two weeks using local reference material (Teketay, 2005). Those seedlings emerged from the soil seed bank in the glass house difficult to identify were transplanted and grown to a larger stage to make identification easier and accurate (Teketay, 2005). However, in this study, there were no such problems faced because the identification of seedlings was done by using both combinations of taxonomic experts and local peoples who were lived in the surrounding area.

\section{Data Analysis}

Descriptive and inferential statistics were used for data presentation and analysis. MS-Excel was used for data organization of the forest tree density, relative abundance, species richness, and evenness. Analysis of Variance (one way ANOVA) was carried out using SPSS program version 25 to test the effect of plantation forest with and without management intervention and adjacent natural forest on diversity and regeneration status and role of soil seed bank for regeneration. During the ANOVA test, the number of species, stem density and the soil seed bank community was the dependent variables while the study treatments or plantation forest types with management intervention and adjacent forest were considered as the independent variables which were a determinate factor for the above listed dependent variables. Data were checked for homogeneity of variances to assess the equality of variances, while normality was checked in the test and some data parameters are not normal, then, data were log transformed. 


\section{Vegetation Data Analysis}

Species diversity and richness in Tarmaber plantation with different management intervention and the adjacent natural forest were calculated using the Shannon-Wiener diversity index ( $\left.H^{\prime}\right)$, Shannon evenness index and Margalef index (R) to evaluate species richness (Peet, 1974).

$\mathbf{H}^{\prime}=-\sum_{\mathrm{i}=1}^{\mathrm{k}}$ pi lnpi

Where, $\mathrm{H}^{\prime}$ is Shannon diversity index,

$\mathrm{Pi}$ is the proportion of individuals or the abundance of the $\mathrm{i}^{\text {th }}$ species expressed as a proportion of a total cover,

$\mathrm{K}$ is the number of species and

$\mathrm{Ln}$ is $\log$ basin

The most common and widely used methods for evenness or equitability is based on

Pielou (1966) as follows

$$
\mathbf{J}=\frac{\mathbf{H}}{\mathbf{H}^{I} \max }
$$

Where, $\mathrm{J}$ is evenness,

$\mathrm{H}^{\prime}$ is Shannon-wiener diversity index and

H'max is the maximum Shannon-wiener diversity indexes

$$
\mathbf{R}=\frac{\mathbf{S}^{\prime}-\mathbf{1}}{\mathbf{L n N}} \text { (Margalef, 1958) }
$$

Where, $\mathrm{R}$ is Margalef index of species richness,

$S^{\prime}$ is number of species and

$\mathrm{N}$ is number of individuals

\section{Structural data analysis}

The forest structure would describe in terms of frequency, dominance, basal area per hectare, important value index determination in the following formulas: 
Density determination: - species density was summarized from a total number of individual abundance in each species. It was calculated as follows,

$$
\text { Density }=\frac{\text { Total no. of individuals of the species }}{\text { No.of quadrat per unites studied }} \times 100
$$

Frequency: - the frequency of quadrates occupied by a given species. It was calculated in the following formula

$$
\text { Frequency }=\frac{\text { No.of units in which the species occurred }}{\text { Total no.of unit studied }} \times 100
$$

Relative Density (RD): is defined as the number of all individuals of a given species divided by the total number of all individuals of all species times 100.

Relative Density $=\frac{\text { Density of a given species }}{\text { Total densities of all the species }} \times 100$

Relative Dominance: the area occupied by a given species relative to the total area occupied by all species, where dominance is defined as the mean basal area per tree times the number of trees of the species.

$$
\text { Relative Dominance }=\frac{\text { Basal area of each species }}{\text { Area sample }} \times 100
$$

Relative Frequency (RF): is the distribution of one species in a sample relative to the distribution of all species.

Relative frequency $=\frac{\text { Frequency of species } \mathrm{A}}{\text { Total ferquency of all species }} \times 100$

Important Value Index (IVI): It is an index which describes the structural role of a species in a stand and all woody species population was examined by estimating frequency, relative frequency, density, relative density, dominance and relative dominance (Pichette and Gillespie, 1999). It was calculated as follows based on Kent and Coker, 1992).

Important Value Index $($ IVI $)=R D+R F+R D o$

Where, RD is Relative Density, 
RF is Relative Frequency and

RDO is Relative Dominance

Population Structure: Population structure of tree stem diameter distribution was used to infer regeneration patterns and successional trends in tree population. To determine the population structure, individuals of each species encountered were grouped in to a diameter class and structure of the species was shown using frequency class of diameter and height distribution. According to Peters (1996) frequency class was important to interpret the indication of the regeneration status of the forest.

Regeneration Status: the regeneration status of woody species was summarized based on the total count of seedling, saplings and mature tree stem ha ${ }^{-1}$ of each species across all quadrates and presented in tables and frequency histograms.

\section{Similarity Index}

The similarity analysis is used to identify the highly similar and/or dissimilar stands in their understory plant composition. Most of the time similarity is analyzed using a statistical measure of similarity coefficient of Sorensen and Jaccard's similarity coefficients. But Jaccard's similarity coefficient is most sensitive for extreme error for small sample sizes (Chao et al., 2005). Due to this reason Sorensen similarity coefficient was used to compare the similarity between the forest types in their species richness and to test soil seed bank community and above ground flora similarity for this research. The index is widely used because it gives more weight to the species that are common to the samples rather than to those that only occur in either sample. The similarity (Ss) index was calculated using the formula according to Kent \& Coker, 1992).

$$
S S=\frac{2 \mathrm{a}}{2 \mathrm{a}+\mathrm{b}+\mathrm{c}} \times 100
$$

Where, Ss is Sorenson similarity coefficient a is number of species common to both samples $\mathrm{b}$ is number of species in sample1 $\mathrm{c}$ is number of species in sample 2 


\section{RESULTS AND DISCUSSION}

\section{Woody Species Diversity}

\section{Species Area Curve}

Species area curve shows that the relationship between the area and the number of species found within that area and it is very important to determine the sufficiency of the sample plot (Scheiner et al., 2000).

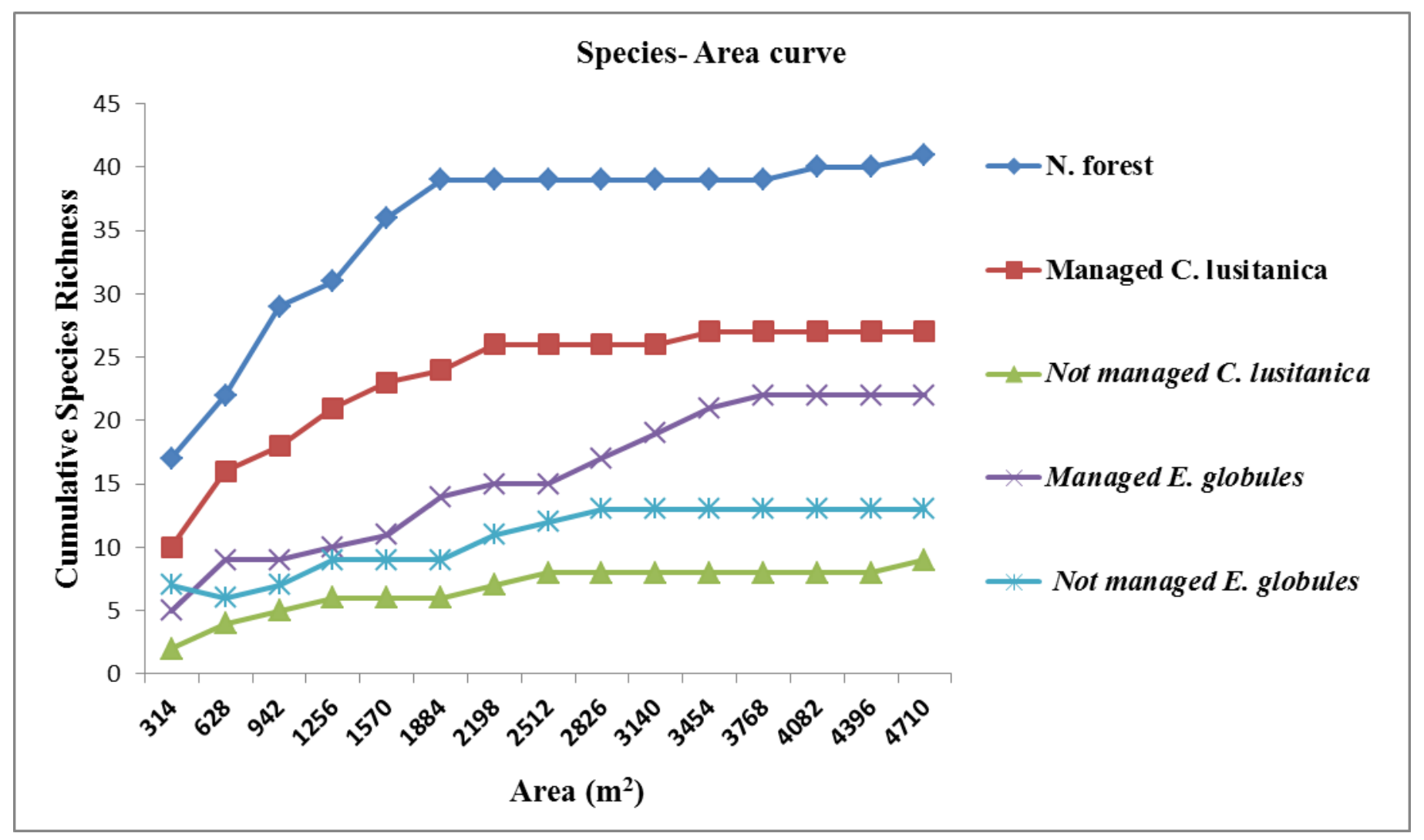

Figure 4: Species-area curve of all species in managed and unmanaged Tarmaber plantation forest and adjacent natural forest.

The species area curve was developed from 75 sample plots, which covered an area of 2.355 ha. In the case of plantation forest with management intervention and adjacent natural forest, the pattern of the curve shows an increasing the number of woody species in the starting phase with increasing areas up to a $2198 \mathrm{~m}^{2}, 3454 \mathrm{~m}^{2}, 4082 \mathrm{~m}^{2}, 3140 \mathrm{~m}^{2} \& 3140 \mathrm{~m}^{2}$ for natural forest, managed $C$. lusitanica, not managed $C$. lusitanica, managed E. globules and not managed E. 
globules respectively. And this assumption is scientifically true, when the species diversity increased with the increasing of area (Lawson \& Henrik, 2006). Also in this study, the numbers of species become constant after above points for each forest types and made curve flat (Figure 5). Normally based on curve formation, it confirmed that 15 sample plots for each forest types were sufficient and it can represent the entire population and generated good information about the composition, diversity and species richness in the study area (Khaine et al., 2017).

\section{Floristic Composition}

For this study, list of the naturally regenerated woody species in managed and unmanaged plantation forests and the adjacent natural forest stand had a total of 51 woody species with 31 families and 1265 individuals were recorded (Table 2). The present study both in adjacent natural and plantation forest were (i.e. 51 species), which were close to the Munessa-Shashemene forest (i.e.55 species) reported by Feyera \& Demel (2002). And it had higher number of species compared to Menagesha-Suba dry Afromontane forest (i.e. 42 species) reported in central Ethiopia (Feyera \& Demel, 2001). The higher number of species recorded in this study under plantation forest and natural forest compared to Menagesha-Suba dry Afromontane forest could be due to the reason of environmental difference, human and animal interference, and altitude difference among the forests. Since Munessa-Shashemene and Menagesha-Suba dry Afromontane forest found in the altitude of 2200 to $3000 \mathrm{~m}$. a .s, whereas this study was conducted at 2800 to $3500 \mathrm{~m}$. a.s. The life form of the plants according to the classifications of Getachew \& Biruk (2014), among 51 native woody species 17 species were trees, 36 were shrubs, and 6 species were shrub/woody climbers .

The species composition in different forest stands ranged from 9 to 41 species in the study area. The number of species recorded in unmanaged $C$. lusitanica plantation was 9 species, whereas in managed $C$. lusitanica plantation 27 species were recorded. Also in unmanaged E. globules plantation (without enrichment planting) and managed E. globules (with enrichment planting) had 13 and 22 species respectively. However in adjacent natural forest 41 species was recorded and highest among other plantation forests. The highest number of species was found in the natural forest stand, which confirms to the results from previous studies in Yeraba priority state forest, Amhara Region, Ethiopia (Getachew \& Biruk, 2014). Whereas among plantation stands, the highest number of species was recorded in managed $C$. lusitanica (with pruning management intervention) plantation stand and the least numbers of species are recorded in not managed $C$. 
lusitanica (without pruning management intervention) plantation stand in the study area. This result also confirmed by (Bauhus \& Schmerbeck, 2010) the effect of management on diversity. Least number of species recording in not managed $C$. lusitanica is in line with the study of Abrham et al. (2011) under Cupressus and Eucalyptus species low understory plant recruitments were recorded in cupressus plantation than eucalyptus plantation without any enhancing management interventions. Such variations are attributed to standing canopy characteristics that determine the number of canopy gaps available for solar radiation, which influences the environmental conditions at the forest floor such as light and air and soil temperatures.

Table 2: Family of the dominant woody species in Tarmaber plantation forest and adjacent natural forest at Tarmaber North Shewa Zone, Ethiopia

\begin{tabular}{|l|l|l|l|}
\hline No. & Family & Number of Species & No. of Individuals \\
\hline 1 & Asteraceae & 5 & 73 \\
\hline 2 & Lamiaceae & 3 & 19 \\
\hline 3 & Myrsinaceae & 3 & 40 \\
\hline 4 & Rosaceae & 3 & 36 \\
\hline 5 & Rubiaceae & 3 & 50 \\
\hline 6 & Anacardiaceae & 2 & 18 \\
\hline 7 & Cupressaceae & 2 & 396 \\
\hline 8 & Melianthaceae & 2 & 15 \\
\hline 9 & Moraceae & 2 & 33 \\
\hline 10 & Solanaceae & 2 & 105 \\
\hline & Others 11-31 & 24 & 480 \\
\hline & Total & 51 & 1265 \\
\hline
\end{tabular}

\section{Species Frequency Class}

Frequency expresses how frequently the species is observed in all samples. In other words it explains its distribution over the forest (Kebede et al., 2013). In this study plantation forest with management intervention and adjacent natural forest tree species were categorized under five frequency classes according to Raunkiaer's frequency classes (Robert, 1962) (Figure 6). High number of species were found in frequency class of 1-20\%) and 21-40\%) and it gradually 
decreases the number of species in frequency class of 41-60\%), 61-80\%) and class (81-100\%). This result indicated that more than $80 \%$ of the species found in the absolute class of $1-20 \%$ and $21-40 \%$, which means that high value in the lower frequency classes and low values in the higher frequency classes indicated that high floristic heterogeneity occurred, but the reverse of this result displayed similar or constant species composition (Abyot et al., 2014).

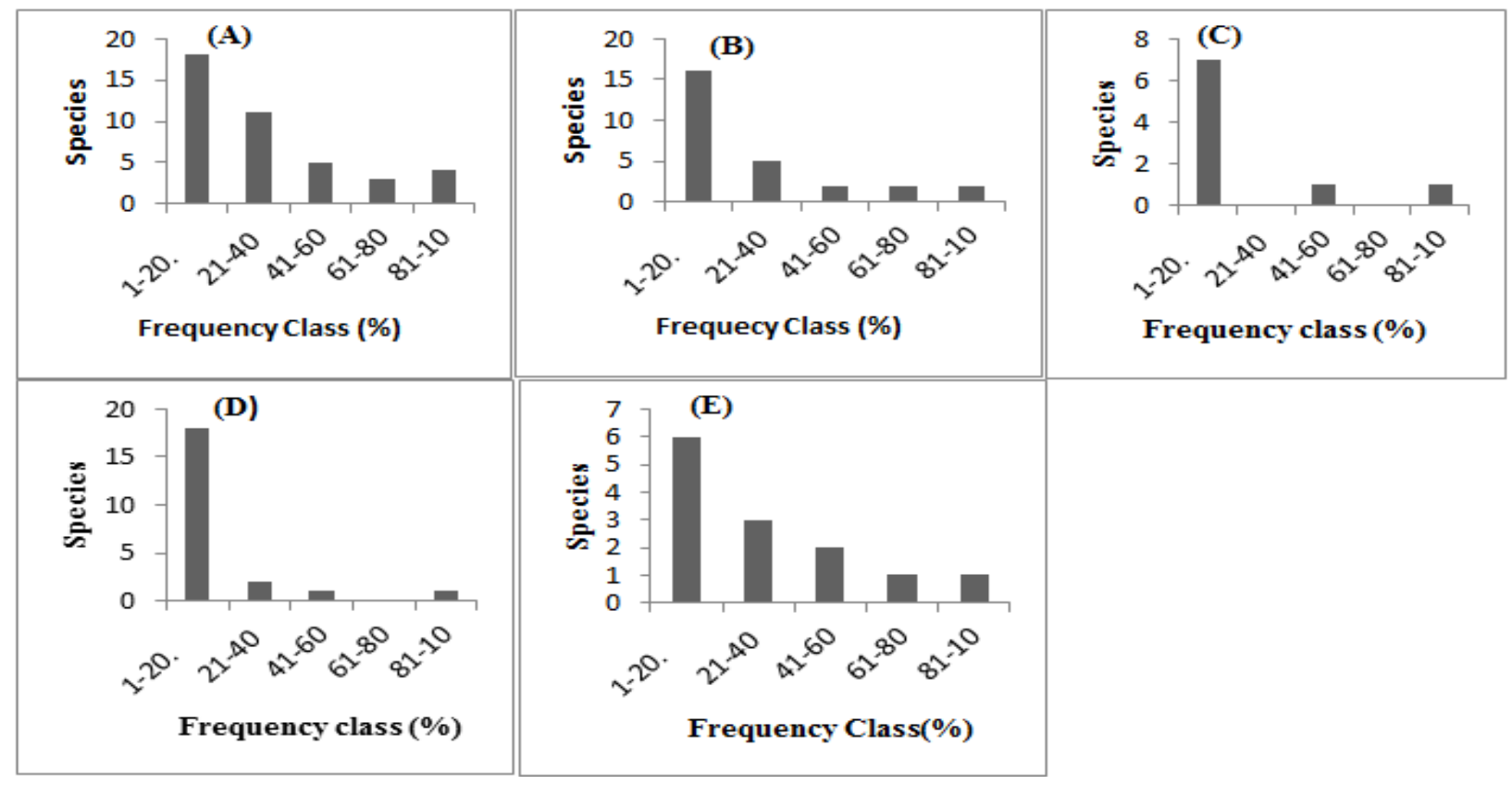

Figure 5: Frequency diagram of woody species in managed and unmanaged plantation forest and adjacent natural forests. A (natural forest), B (Managed C. Lusitanica), C (Not managed $C$. lusitanica), D (Managed E. globulus) and E (Not managed E. globulus)

Frequency: The most frequently found species (frequency $\geq 50 \%$ ) are described for each forest types. In natural forest (10), managed C. lusitanica (5), in not managed C. lusitanica (2), managed E. globules (2) and in not managed E. globules (3) species were recorded in this study (Table 3). The remaining species found less than $50 \%$ frequency and the minimum frequency for each forest types in 75 quadrats was 7\%. This means out of the 75 sampled quadrates these species were encountered only in seven quadrants. This implies that these particular species are rare relative to the other species and may become nonexistent from the study forest in the future (Getachew \& Biruk, 2014). 
Table 3: List of the most frequently found species $(\mathrm{F} \geq 50 \%)$ in all sampled stands at Tarmaber plantation forest and in adjacent natural forests in North Shewa Zone, Ethiopia

\begin{tabular}{|c|c|c|c|}
\hline Forest types & Species name & Local name & $\begin{array}{l}\text { Frequency } \\
(\%)\end{array}$ \\
\hline \multirow[t]{10}{*}{ Natural forest } & Allophylus abyssinicus & Embus & 53 \\
\hline & Discopodium penninervum & Ameraro & 80 \\
\hline & Dovyalis abyssinica & Koshem & 53 \\
\hline & Galiniera saxifrage & Yetota kula & 80 \\
\hline & Juniperus procera & Habesha tisde & 93 \\
\hline & Maesa lanceolata & Kelewa & 87 \\
\hline & Maytenus arbutifolia & Atate & 87 \\
\hline & Morus mesozygia & Injory & 60 \\
\hline & Olea africana & Woyera & 73 \\
\hline & Vernonia auriculifera & Gujo & 93 \\
\hline \multirow[t]{5}{*}{ Managed C. lusitanica } & Cupress lusitanica & Yefereje tisd & 87 \\
\hline & Discopodium penninervum & Ameraro & 93 \\
\hline & Erica arborea & Aseta & 73 \\
\hline & Juniperous procera & Habsha tisd & 80 \\
\hline & Vernonia auriculifera & Gujo & 60 \\
\hline \multirow[t]{2}{*}{ Not managed $C$. lusitanica } & Erica arborea & Aseta & 87 \\
\hline & Juniperous procera & Habesha tsid & 50 \\
\hline \multirow[t]{2}{*}{ Managed E. globules } & Discopodium penninervum & Ameraro & 53 \\
\hline & Juniperous procera & Habesha tsid & 100 \\
\hline \multirow[t]{3}{*}{ Not managed E. globules } & Erica arborea & Aseta & 93 \\
\hline & Lobelia rhynchopetalum & Jibra & 67 \\
\hline & Pentas schimperiana & Woyinagifet & 60 \\
\hline
\end{tabular}

\section{Species Diversity, Richness and Density}

The highest mean number of species was found in the natural forest $(15 \pm 0.65)$ followed by managed $C$. lusitanica $(8 \pm 1.05)$ and the least mean number of species was recorded at unmanaged $C$. lusitanica $(2 \pm 0.18)$ (Table 4). There was a significant difference between forest types $(\mathrm{F}=62.43, \mathrm{p}<0.05)$. Similar results reported by Shiferaw \& Tadesse (2009) in Belete state forest and Abrham et al. (2011) in Tehuledere district showed natural forest have more number of species than plantation forest. Depending on this result managed $C$. lusitanica and natural forest was highly significantly differed between them and other unmanaged plantation forests types $(\mathrm{F}=62.43, \mathrm{p}<0.05$ (Table 4). Similar results also reported in Vietnam by Millet et al. (2013) 
Enrichment planting of native species in a logged tree plantation increases the number of tree species in the understory vegetation. In addition, Jennifer \& Alistair (2013) reported that silvicultural activities like pollarding, pruning and coppicing enhance vegetation regeneration plant species composition under exotic plantation forests. This is because silvicultural treatment affects soil and water content and nutrient availability and sunlight penetration that create an opportunity for understory vegetation growth. So from this study, the number of species increases from unmanaged plantation forest to managed plantation forests and to natural forest. Also in comparison of plantation forest and natural forest in woody species regeneration with appropriate management interventions like seed source or planting materials, availability of remnant patch natural forests and dispersing agent made increasing the number of species. But with absence of these management activity clamming plantation forest for negatively on species abundance and composition is a wrong way in scientific and local communities in different parts of the world (Bernes et al., 2014).

Table 4: Woody species along plantation forest with management intervention and adjacent natural forest $(\mathrm{F}=62.43, \mathrm{p}=0.000 ; \mathrm{n}=15)$

\begin{tabular}{|l|l|l|l|l|l|}
\hline Forest types & Mean \pm SE & SD. & Min & Max & CV\% \\
\hline Natural forest & $15 \pm 0.65^{\mathbf{c}}$ & 2.52 & 11 & 20 & 17 \\
\hline Managed C. lusitanica & $8 \pm 1.05^{\mathbf{b}}$ & 4.05 & 1 & 14 & 51 \\
\hline $\begin{array}{l}\text { Not managed } \\
\text { C. lusitanica }\end{array}$ & $2 \pm 0.18^{\mathbf{a}}$ & 0.70 & 1 & 4 & 33 \\
\hline Managed E. globules & $5 \pm 0.38^{\mathbf{a}}$ & 1.51 & 2 & 7 & 34 \\
\hline $\begin{array}{l}\text { Not managed } \\
\text { E. globules }\end{array}$ & $4 \pm 0.53^{\mathbf{a}}$ & 2.07 & 1 & 8 & 50 \\
\hline Sig (5\%) & $* *$ & & & & \\
\hline
\end{tabular}

The Margalef richness indices Table 5 confirmed that the natural forest stand was richer in regenerated species than plantation stands $(\mathrm{R}=6.8)$. And among plantation forest stands managed C. lusitanica stand was richer than others $(\mathrm{R}=4.32)$. Not managed E. globules and C. lusitanica had the least species richness $(\mathrm{R}=2.2$ and 2.03) respectively (Table 5). The existence of rare species made the richness result higher in the natural forest and 13 species were found in a natural forest and these were not found on the plantation stands. Among plantation stands, the $C$. 
lustanica and E. globules with management intervention contained 10 more species, which were not found in natural forest.

Shannon diversity index (H') is taking in to account the number of individuals as well as the number of species. Shannon diversity varies from 0 for a community with only a single species to a high value for a community with many species and in theory, this can reach very large values. However, in practice for biological communities, H' does not exceed 5.0 (Krebs, 1999 as cited in Alemayehu, 2002). Shannon diversity index is high when it is above 3.0, medium when it is between 2.0 and 3.0, low between 1.0 and 2.0, and very low when it is smaller than 1.0 (Cavalcanti and Larrazabal, 2004 as cited in Temesgen et al., 2015). From this study, the natural forest showed high diversity; managed $C$. lusitanica had medium diversity and the unmanaged plantation forest had low diversity (Table 5).

And the species evenness ranges from zero 0 to 1 , with zero signifying no evenness and one, a complete evenness (Pielou, 1966). From this study all forest types had high evenness (Table 5) except managed E. globules had low evenness (0.33) values, because it might be biased from some important group of species during enrichment planting. This reason was similar in the study of species diversity by artificial restoration for coniferous forests in Southwest China (Qiaoying et al., 2006). Generally in this study more or less even representation of individuals of all species encountered in the studied quadrants except a few species are dominant. 
Table 5: Species richness computation using Margalef index (R) and Shannon diversity index in different forest stands in Tarmaber forest North Shewa Zone, Ethiopia

\begin{tabular}{|l|l|l|l|l|l|l|}
\hline No. & Treatments & S & N & $\begin{array}{l}\text { Diversit } \\
\text { (H') }\end{array}$ & $\begin{array}{l}\text { Evenness } \\
\left(\mathrm{H}^{\prime} / \mathrm{lnS}\right)\end{array}$ & $\begin{array}{l}\text { R (Margalef } \\
\text { richness index })\end{array}$ \\
\hline 1 & Natural forest & 41 & 359 & 3.32 & 0.89 & 6.80 \\
\hline 2 & Managed C. lusitanica & 27 & 409 & 2.25 & 0.68 & 4.32 \\
\hline 3 & Not managed C. lusitanica & 11 & 52 & 1.29 & 0.59 & 2.03 \\
\hline 4 & Managed E. globules & 22 & 211 & 1.83 & 0.33 & 3.92 \\
\hline 5 & Not managed E. globules & 13 & 233 & 1.8 & 0.70 & 2.20 \\
\hline
\end{tabular}

There was a significant difference in the mean stem density of woody species among the different forest types $(\mathrm{F}=13.01, \mathrm{p}<0.05)$. Not managed $C$. lusitanica forest was significantly lower than other forest types. Whereas the managed C.lusitanica plantation is significantly higher than other forest types except the adjacent natural forest (Table 6). From this result with appropriate management intervention in plantation forest can enhance species composition, species diversity and good regeneration as equally as in natural forests (Nagaraja et al., 2011). Regeneration in the understory of the managed plantations differed from that of an unmanaged plantation forests. This implies that management intervention like spacing, enrichment planting, pruning and pollarding can offer opportunities for species richness (Bauhus \& Schmerbeck, 2010); (Kerr, 2015); (Petit \& Montagnini, 2006).

Table 6: Mean stem density $\mathrm{ha}^{-1}$ in managed and unmanaged plantation forest and adjacent natural forests (ANOVA, $\mathrm{F}=13.01, \mathrm{p}=0.000, \mathrm{n}=15$ ).

\begin{tabular}{|l|l|l|l|l|l|}
\hline Variables & Forest types & Mean \pm S.E & SD. & Min & Max \\
\hline Stem density ha & Natural forest & $762 \pm 83.64^{\mathbf{b c}}$ & 323.95 & 414 & 1465 \\
\cline { 2 - 6 } & Managed C. lusitanica & $868 \pm 99.92^{\mathbf{c}}$ & 386.99 & 382 & 1592 \\
\cline { 2 - 6 } & Not managed C. lusitanica & $110 \pm 11.09^{\mathbf{a}}$ & 42.94 & 32 & 191 \\
\cline { 2 - 6 } & Managed E. globules & $450 \pm 58.05^{\mathbf{b}}$ & 224.80 & 191 & 924 \\
\cline { 2 - 6 } & Not managed E. globules & $494 \pm 115.47^{\mathbf{b}}$ & 447.23 & 64 & 1497 \\
\cline { 2 - 6 } & Sig (5\%) & $* *$ & & & \\
\hline
\end{tabular}

**, significant at $1 \%$ level; *, significant at $5 \%$ level; ns, not significant 


\section{Similarity in Species Composition between Different Plantation Forests and Adjacent Natural Forest}

The similarity in species composition of the plantations to the natural forests could determine the plantations that eventually undergo secondary succession to be replaced by indigenous woody species that closely resemble the floristic composition of the natural forest. The results of the study showed that the not managed $C$. lusitanica plantation exhibited the least similarity in species composition to the natural forest and other managed plantations, while the managed $C$. lusitanica plantation was the most similar to the natural forest (Table 7). The similarity indices determine if the composition of a future secondary forest that replaces the plantation forest would be similar to the natural forest (Pande et al., 1988).

The similarity in species composition between the five forest types was ranged from the similarity index values of 0.312 (between managed E. globules forest and not managed C. lusitanica plantation forest) to 0.653 (between managed C. lusitanica and managed E. globules plantation forests) (Table 7). Generally, natural forest and managed plantation forest have high similarities which, most of the forest types had a score of a similarity index value between 0.4070.653. This result also is inline with Shiferaw \& Tadesse (2009) in the study of a comparative assessment on regeneration status of indigenous woody plants in Eucalyptus grandis plantation and adjacent natural forest in Belete state forest. From the total similarity index values, the better similarity was observed between managed C. lusitanica and managed E. globules plantation forests because these forests were located close to each other or there were either similar seed dispersal mechanisms or the forests could have similar soil seed banks (Omoro \& Luukkanen, 2011). 
Table 7: Sorenson's similarity index and the number of common woody species composition between the different forest types (* the lowest similarity, ** the highest similarity).

\begin{tabular}{|l|l|l|l|l|l|}
\hline Forest types & $\begin{array}{l}\text { Natural } \\
\text { forest }\end{array}$ & $\begin{array}{l}\text { Managed } \\
\text { C. lusitanica }\end{array}$ & $\begin{array}{l}\text { Not managed } \\
\text { C. lusitanica }\end{array}$ & $\begin{array}{l}\text { Managed } \\
\text { E. globules }\end{array}$ & $\begin{array}{l}\text { Not managed } \\
\text { E. globules }\end{array}$ \\
\hline Natural forest & & 0.588 & 0.320 & 0.590 & 0.407 \\
\hline Managed C. lusitanica & & & 0.444 & $0.653^{* *}$ & 0.55 \\
\hline Not managed C.lusitanica & & & & $0.312^{*}$ & 0.545 \\
\hline Managed E. globules & & & & & 0.388 \\
\hline Not managed E. globules & & & & & \\
\hline
\end{tabular}

\section{Basal Area}

The basal area distribution is very important criteria for determining and classifying forest types and often important for forest management decisions such as estimating forest regeneration (Hökkä et al., 1997). Total woody species basal area among the forest types of the study area was high in the natural forest $\left(27.56 \mathrm{~m}^{2} \mathrm{ha}^{-1}\right)$ and low in an unmanaged $C$. lusitanica plantation forest $\left(0.18 \mathrm{~m}^{2} \mathrm{ha}^{-1}\right)$ (Figure 7$)$. The comparison of the total basal area of the adjacent natural forest had a higher basal area to plantation forest. Generally, in this study, the basal area of adjacent natural forest was very low even when it compared to the basal area of tropical forests $35 \mathrm{~m}^{2} \mathrm{ha}^{-1}$ (Midgley \& Niklas, 2004). However, it had a greater basal area, which reported from Bale Mountain National park, Boditi Forest ( $23 \mathrm{~m}^{2} \mathrm{ha}^{-1}$ ) (Yineger et al.,2008); Zengena Forest (22.3 $\mathrm{m}^{2} \mathrm{ha}^{-1}$ ) (Tadele et al.,2014) and Hugumburda forest (9.23 $\mathrm{m}^{2} \mathrm{ha}^{-1}$ ) (Aynekulu, 2011). Among plantation forests, the managed stands of plantation forests had a higher basal area with relative to an unmanaged plantation forest (Figure 7). The management effect on the basal area among plantation forest had good indication of natural regeneration in terms of basal area and number of species compared to unmanaged plantation stands. Similar studies conducted in Britain showed that the use of silvicultural systems like pruning, pollarding and coppicing enhance the biological diversity of indigenous tree species basal area and good regeneration under plantation forest (Kerr, 2015). Other studies conducted enrichment planting of indigenous tree species in plantations forest in Costa Rica was found to be more successful in tree stem regeneration and good basal area under the forest plantations (Petit \& Montagnini, 2006). 


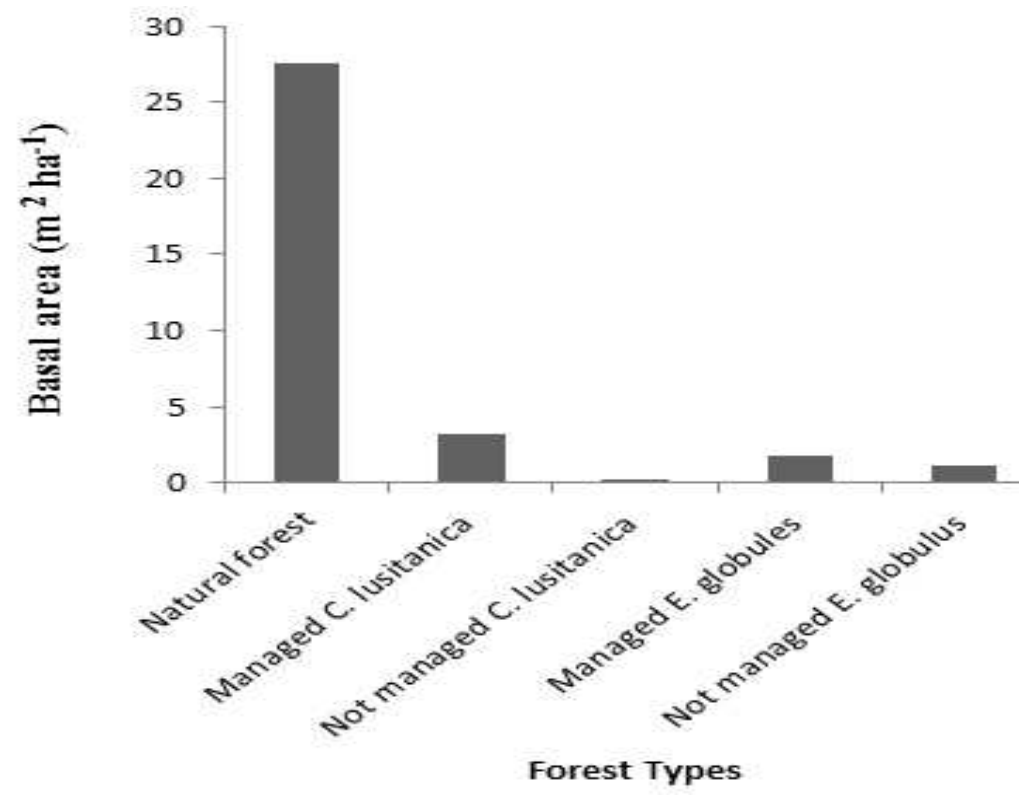

Figure 6: Basal area of plantation forest with and without management intervention and adjacent natural forest

The basal area of natural regenerated plants under plantation forest with and without management intervention and adjacent natural forest was classed in to five classes (Figure 8). The number of species found in an unmanaged plantation forest had only basal area $<1 \mathrm{~m}^{2} \mathrm{ha}^{-1}$ and the managed plantation forest and adjacent natural forest some species had above $1 \mathrm{~m}^{2} \mathrm{ha}^{-1}$ basal area and most species had $<1 \mathrm{~m}^{2} \mathrm{ha}^{-1}$. This is the reason behind the management effect that made basal area difference across all forest types in a similar environment and agroecology situations. Also the number of species in each forest types laid in the lower basal area class, the managed plantation stand and natural forests showed good regeneration capacity. Nenninger et al. (2012) also confirmed that appropriate silvicultural treatments in plantation forests enable to increase the productivity of the harvestable stand in terms of mass values and it converts plantation forests of exotic tree species into natural forests by enhancing of undergrowth native trees regeneration. 


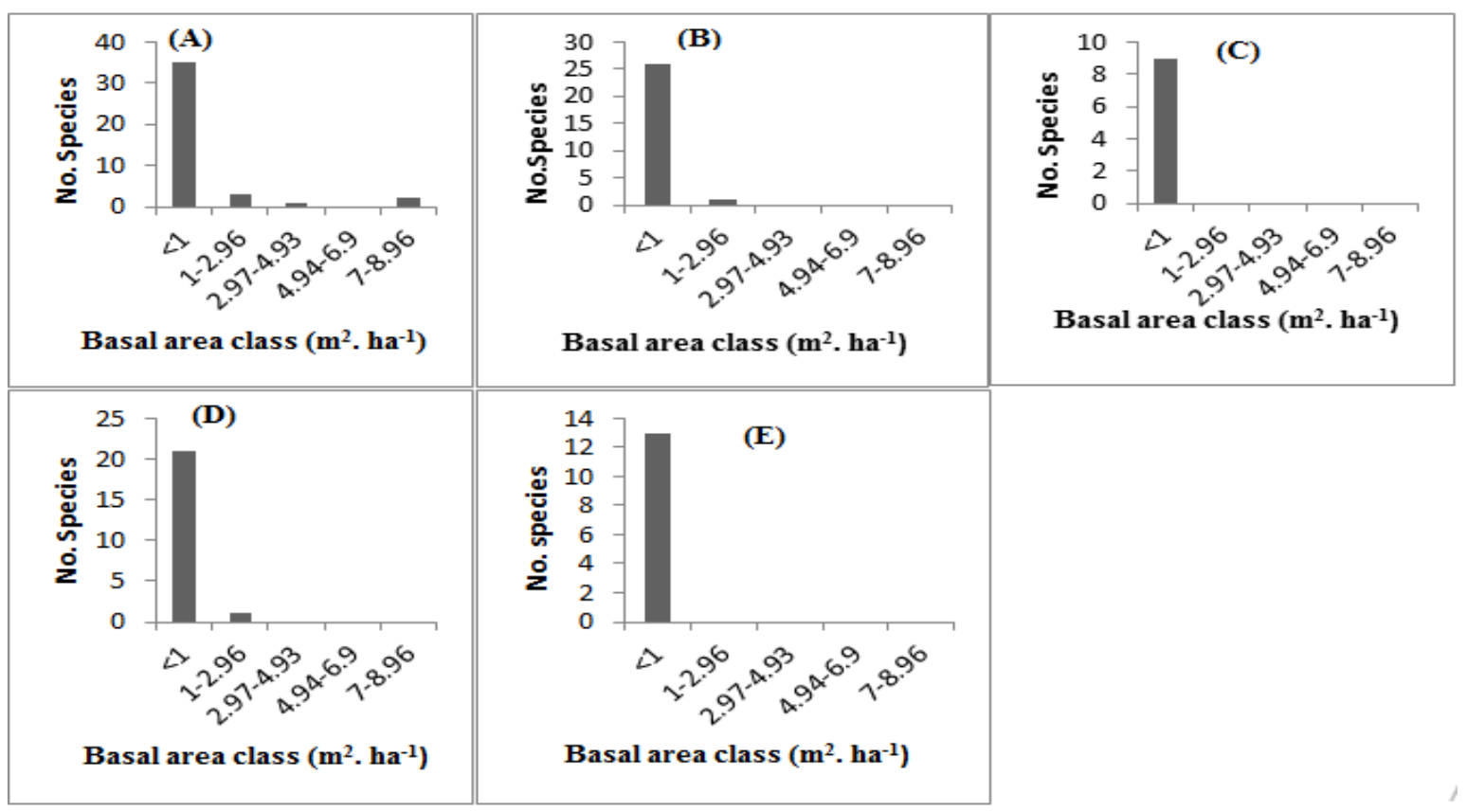

Figure 7: Number of woody species in different forest types of plantation forest and adjacent natural forests. A (natural forest), B (Managed C. Lusitanica), C (Not managed C. lusitanica), D (Managed E. globulus) and E ( Not managed E. globulus)

\section{Importance value index (IVI)}

It provides the measure of the relative importance of the species than simple count and species with the largest value in dominance could be considered as the most important species in the study area (Ajayi \& Obi, 2016).

In this study ten most important woody species in the adjacent natural forest with the highest import value index are Juniperus procera Olea eurpeana, Ficus sur, Vernonia auriculifera, Prunus africana, Discopodium penninervum, Maesa lanceolata, Rhus glutinosa, Maytenus arbutifolia and Allophylus abyssinicus. These species contributed to over $64 \%$ of the total import value index. Whereas in the managed C. lusitanica plantation stand more than $61 \%$ of the IVI is dominated by 6 species which, are Juniperous procera, Discopodium penninervum, Erica arborea, Vernonia auriculifera, Myrica salicifolia and Hagenia abyssinica (appendix 3). In not managed C. lusitanica plantation stand, more than $80 \%$ of the IVI was covered by Erica arborea and Juniperous procera. In managed E. globules more than $64 \%$ of the IVI was occupied by Juniperous procera and Discopodium penninervum, and in not managed E. globules plantation Erica arborea, Juniperus procera and Hagenia abyssinca was the most important species in the 
study area. Generally, in plantation forest with and without management intervention and adjacent natural forest the most important species was Juniperus procera. Similar results were reported in the study of Ethiopian highland forests Juniperous procera tree species was existed under the canopy of plantation forest (Getachew \& Biruk, 2014; Hundera, 2011; Shiferaw, 2006). Also in this study the focus group discussion and key informants 'confirmed that Juniperous procera can exist in exotic plantation forest without inferior to the existed exotic plantation forest stand. Because in this study area before converting to plantation forest scattered Juniperus procera trees was found. And the tree had wider agroecology $(1750-3500 \mathrm{~m})$ and mostly the plant existed rocky basalt soil types (Hall, 2009).

\section{Stand Structure}

\section{Mean Diameter and Height}

The study of undergrowth woody vegetation in plantation forest with and without management intervention and adjacent natural forest stand structure are very important for future management plan (Eslami et al., 2011). The mean Diameter at Breast Height (DBH) and mean height of Tarmaber plantation forest with and without management intervention and adjacent natural forest was illustrated in (Table 8).

The result indicated that the mean DBH and height of woody species both in plantation and adjacent natural forest had varied results due to management effects in the plantation forest (Table 8). The standard deviation of diameter and height were higher because of the variation of individual trees. This results was confirmed by (Karlsson, 2013) on his dessiretation in Swedish University of Agricultural Sciences on silvicultural regimes and early biomass thinning in young, dense pine stands. 
Table 8: Mean diameter and mean height of Tarmaber plantation forest with management intervention and adjacent natural forest at Tarmaber North Shewa Zone Ethiopia

\begin{tabular}{|c|c|c|c|c|c|c|}
\hline Forest types & $\mathrm{N}$ & Variables & Mean \pm SE & Min & Max & SD. \\
\hline \multirow[t]{2}{*}{ Natural Forest } & 209 & DBH (cm) & $20.51 \pm 1.86$ & 2 & 115 & 26.83 \\
\hline & 209 & Height (m) & $12.54 \pm 1.02$ & 2 & 43 & 14.73 \\
\hline \multirow{2}{*}{$\begin{array}{l}\text { Managed } \\
\text { C. lusitanica }\end{array}$} & 173 & DBH (cm) & $8.53 \pm 0.65$ & 2 & 44.6 & 8.55 \\
\hline & 173 & Height (m) & $6.55 \pm 0.51$ & 2 & 28 & 6.71 \\
\hline \multirow{2}{*}{$\begin{array}{l}\text { Not managed } \\
\text { C. lusitanica }\end{array}$} & 22 & $\mathrm{DBH}(\mathrm{cm})$ & $6.22 \pm 0.92$ & 2 & 22 & 4.33 \\
\hline & 22 & Height (m) & $3.92 \pm 0.83$ & 2 & 19 & 3.90 \\
\hline \multirow{2}{*}{$\begin{array}{l}\text { Managed } \\
\text { E. globulus }\end{array}$} & 150 & $\mathrm{DBH}(\mathrm{cm})$ & $7.86 \pm 0.44$ & 2 & 35 & 5.38 \\
\hline & 150 & Height (m) & $5.36 \pm 0.33$ & 2 & 19 & 4.01 \\
\hline \multirow{2}{*}{$\begin{array}{l}\text { Not managed } \\
\text { E. globulus }\end{array}$} & 127 & $\mathrm{DBH}(\mathrm{cm})$ & $6.58 \pm 0.47$ & 2 & 18 & 3.58 \\
\hline & 127 & Height (m) & $3.85 \pm 0.30$ & 2 & 19 & 3.40 \\
\hline
\end{tabular}

Remark: $\mathrm{N}$ is sample tree population that were measured height and diameter

Diameter distribution plays a significant role in forest science and used to determine the optimum selective cutting that improves the stand structure (Linares et al., 2011). The overall distribution of diameter classes of individuals of all the species in the study area (Figure 9) in natural forest, managed $C$. lusitanica and in managed E. globules indicated a relatively high proportion of individuals in the lowest diameter class (seedlings), which ensures the potential of recruitment of sustained future regeneration of the forest. However, the decline of number of individuals in the higher diameter classes considerably suggesting that there is unplanned and unsustainable exploitation of woody species in the forest by the local people for domestic consumption and generating income. This result is similar to the study of Zegie, north western Ethiopia (Alelign et $a l ., 2007)$. In an unmanaged $C$. lusitanica and E. globules a bell shaped distribution skewed to the right which is normal in plantation forests (Varga., 2015). From here, the overall distribution of diameter classes of individuals of all the species are dominated by a relatively high proportion of individuals in the lowest diameter class (seedlings) that ensure sustained regeneration of forests. 


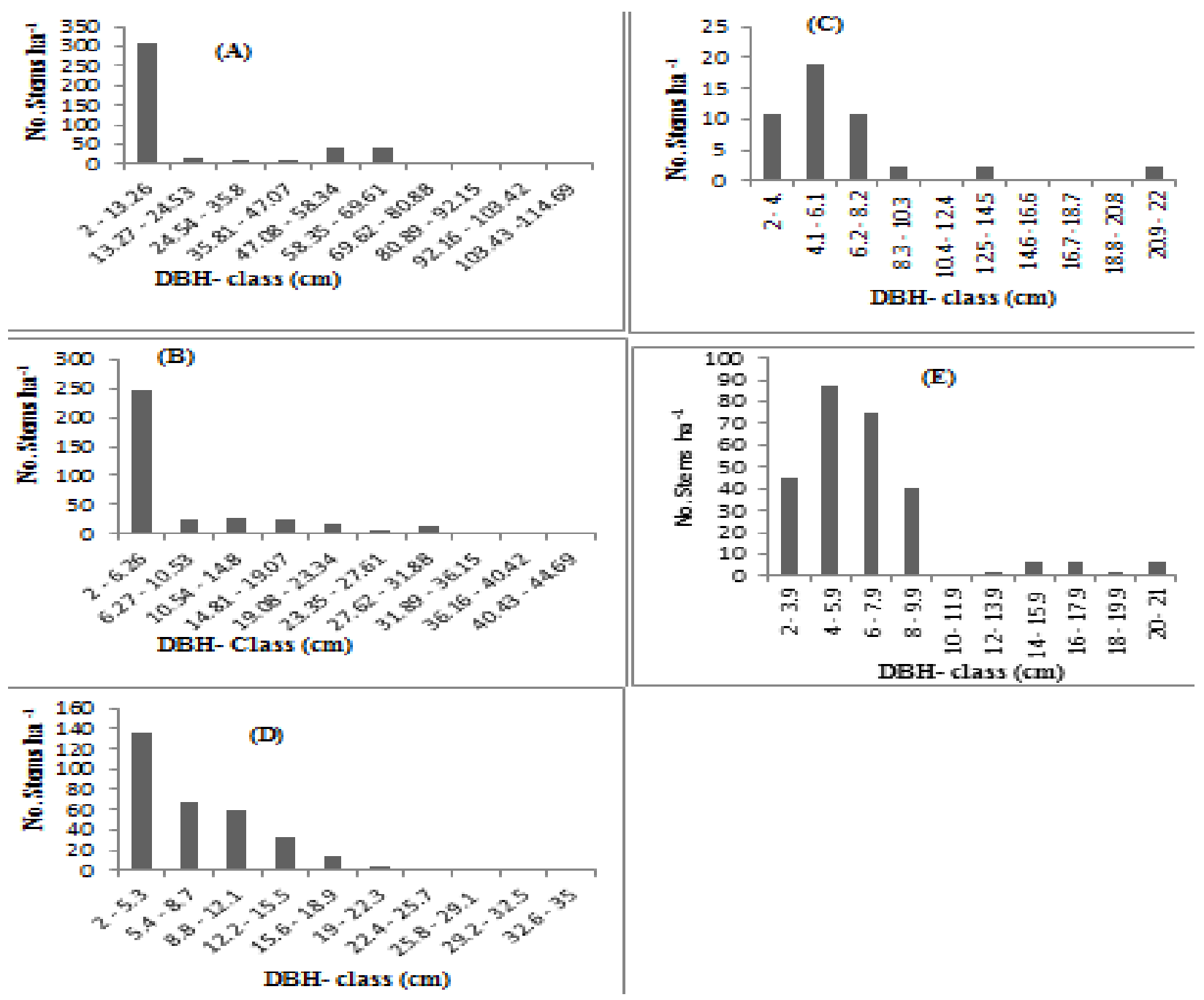

Figure 8: Diameter frequency distribution of Woody species of in managed and unmanaged plantation forest and adjacent natural forests. A (natural forest), B (Managed C. lusitanica), C (Not managed C. lusitanica), D (Managed E. globulus) and E ( Not managed E. globulus), at Tarmaber North Shewa Zone, Ethiopia

Like diameter distribution, the height distributions of the study area were performed. The height distribution in each study forest types showed an inverse -J shaped curve (Figure 10). The number of stems ha ${ }^{-1}$ declined with increasing size (height), that is, more number of individuals at lower size classes and very few numbers of individuals in the high height classes. Generally this pattern of height distribution indicated that good regeneration status of the Forest (Tadele, 2004). 


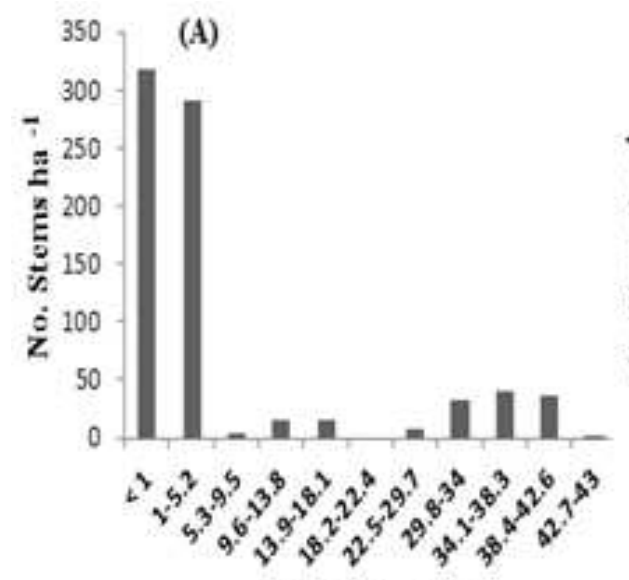

Height-Class (m)

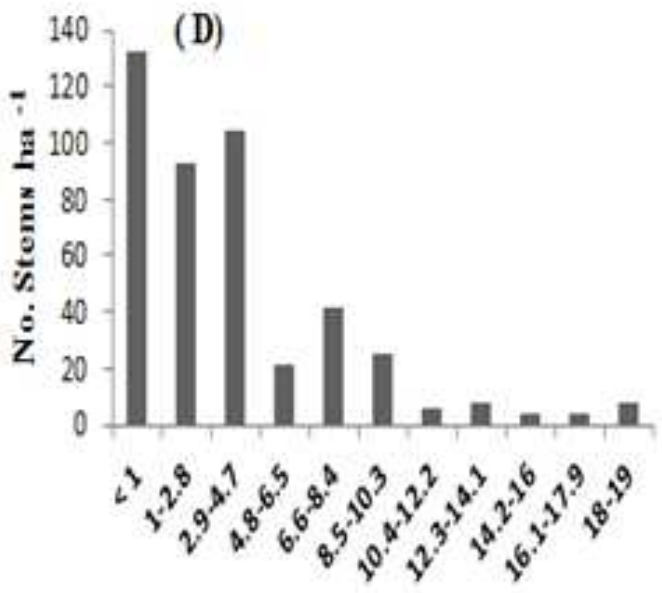

Height-Class (m)

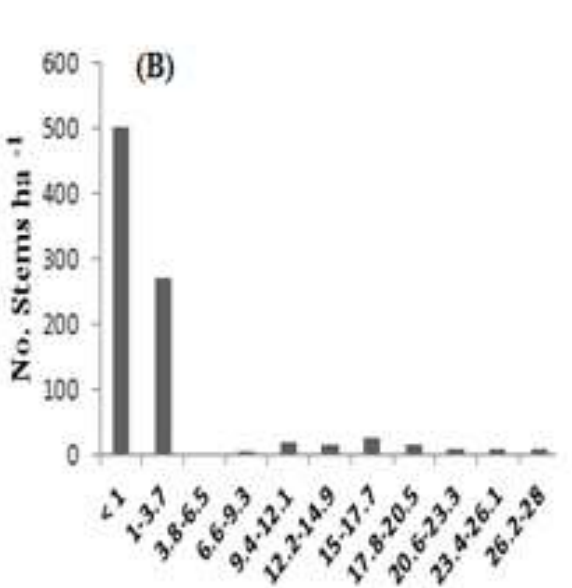

Height-Class (m)

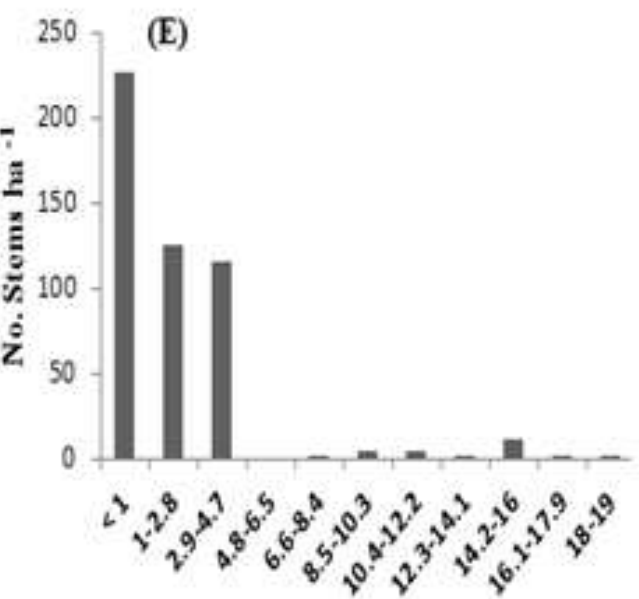

Height-Class ( $m$ )

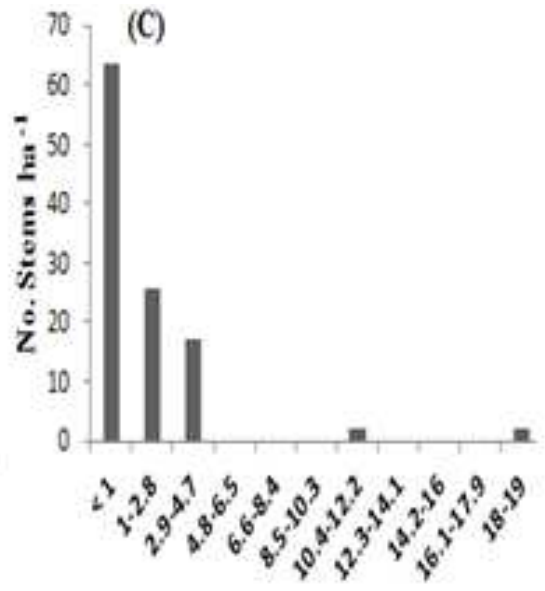

Height-Class (m)

Figure 9: Height frequency distribution of Woody species in managed and unmanaged plantation forest and adjacent natural forests. A (natural forest), B (Managed C. Lusitanica), C (Not managed C. lusitanica), D (Managed E. globulus) and E (Not managed E. globulus) at Tarmaber North Shewa Zone, Ethiopia

\section{Natural Regeneration}

Natural regeneration is the renewal of a tree crop by self-sown seed or by vegetative and soil seed bank means (Minore \& Laacke, 2001); but recently the expansion of exotic plantation forest made a question on the regeneration capacity of native woody species under the canopy of plantation forests. In this study, seedlings with a diameter at breast height $((\mathrm{DBH})<2 \mathrm{~cm}$ and height $<1 \mathrm{~m})$ and saplings between the height of $(1-3$ meter and $\mathrm{DBH}<10 \mathrm{~cm})$ were counted and considered as a seedling and saplings (regeneration) respectively (Ayanaw \& Gemedo, 2018). 
The highest regeneration mean density of mature tree woody species was higher in the natural forest followed by the managed C. lusitanica and least regenerate mean density of mature tree stem $\mathrm{ha}^{-1}$ was recorded in not managed $C$. lusitanica plantation stand among different forest types. Tukey's post hoc analysis showed that the mature tree regenerate mean density in not managed C. lusitanica and E. globules had significantly lower from the mean density of the other managed plantation forest and adjacent natural forest $(\mathrm{F}=14.03, \mathrm{p}<0.05)$. This can possibly be attributed to the lack of nutrient availability, sun-light and moisture stress due to competition. for example, other studies carried out in Cupressus lusitanica plantations in Kibale, Uganda found that the managed Cypress plantations had high species diversity and stem density ha ${ }^{-1}$ indigenous trees under the canopy of plantation forest stand (Colin \& Lauren, 1996).

Saplings of woody tree species are one of the parameters to evaluate the regeneration performance of the plantation and adjacent natural forests (Dupuy \& Chazdon, 2006). The natural forest had the highest regenerate mean density of saplings (Table 9) followed by managed $C$. lusitanica and E. globules stems $\mathrm{ha}^{-1}$. The lowest regenerate mean density of saplings was recorded in the not managed $C$. lusitanica stem ha ${ }^{-1}$. There were significant differences in regeneration between the not managed $C$. lusitanica plantation forest with that of managed plantation forest and unmanaged E. globules and adjacent natural forest $(\mathrm{F}=7.37, \mathrm{p}<0.05)$.

Also seedling is the most critical phase to express regeneration performance among different growth stage of trees (Balliu et al., 2017). The managed C. lusitanica plantation forest had the highest regeneration of seedlings followed by adjacent natural forest and not managed $E$. globules stems $\mathrm{ha}^{-1}$ and the lowest regenerate of seedlings was recorded in not managed $C$. lusitanica stand. This regeneration of seedlings showed significantly different among the different forest types $(\mathrm{F}=16.11, \mathrm{p}<0.05)$. In managed $C$. lusitanica plantation forest, mean seedlings regeneration strongly higher than all other plantation forest types and adjacent natural forest whereas unmanaged E. globules and C. lusitanica and managed E. globules not significantly differed seedling regeneration between them. This result also inline to the study of diversity of native woody regeneration in exotic tree plantations and natural forest in Southern Philippines (Tulod et al., 2017).

The result in Table 9 confirmed that managed $C$. lusitanica have the highest number of seedlings among other forest types and the number of seedlings regeneration under plantation forest with 
and without management intervention and the adjacent natural forest was important to indicate the management effect on regeneration.

When this study result compared to assumption of the regeneration status using the categories had good regeneration status in all forest types that implies the number of stems of seedling density > sapling density> tree density (Table 9).

1. 'Good', if presence of seedling $>$ sapling $>$ mature strata,

2. 'Fair', if presence of seedling > sapling < mature strata;

3. 'Poor', if a species survives only in the sapling stage, but not as seedlings (even though saplings may be <,> or = matured trees;

4. 'None', if a species is absent both in sapling and seedling stages, but present as mature; and

5. 'New', if a species has no mature, but only sapling and/ or seedling stages (Fisaha et al., 2013). 
Table 9: Regeneration of mean densities of mature tree, sapling and seedling in managed and unmanaged plantation forest and adjacent natural forests (ANOVA, F=14.03, F=7.37, F=16.11, $\mathrm{p}=0.000, \mathrm{n}=15$ )

\begin{tabular}{|c|c|c|c|c|c|}
\hline Variables & Forest types & Mean \pm S.E & SD. & Min & Max \\
\hline \multirow[t]{7}{*}{ Tree Density ha ${ }^{-1}$} & & & & & \\
\hline & Natural forest & $154 \pm 19.88^{\mathbf{b}}$ & 77.01 & 0 & 287 \\
\hline & Managed C. lusitanica & $97 \pm 19.75^{b}$ & 76.51 & 0 & 223 \\
\hline & $\begin{array}{l}\text { Not managed } C \text {. } \\
\text { lusitanica }\end{array}$ & $4 \pm 2.91^{\mathrm{a}}$ & 11.26 & 0 & 32 \\
\hline & Managed E. globules & $121 \pm 24.28^{b}$ & 94.04 & 0 & 350 \\
\hline & $\begin{array}{l}\text { Not managed } E \text {. } \\
\text { globules }\end{array}$ & $21 \pm 10.62^{a}$ & 41.13 & 0 & 127 \\
\hline & Sig (5\%) & $* *$ & & & \\
\hline \multirow[t]{6}{*}{ Sapling Density ha ${ }^{-1}$} & Natural forest & $1163 \pm 138.93^{\mathbf{b}}$ & 538.09 & 382 & 2548 \\
\hline & Managed C. lusitanica & $1078 \pm 150.68^{\mathbf{b}}$ & 583.59 & 0 & 1911 \\
\hline & $\begin{array}{l}\text { Not managed } C \text {. } \\
\text { lusitanica }\end{array}$ & $169 \pm 42.45^{a}$ & 164.42 & 0 & 382 \\
\hline & Managed E. globules & $789 \pm 119.36^{\mathbf{b}}$ & 462.29 & 0 & 1656 \\
\hline & $\begin{array}{l}\text { Not managed } E \text {. } \\
\text { globules }\end{array}$ & $985 \pm 222.54^{\mathbf{b}}$ & 861.89 & 0 & 3057 \\
\hline & Sig $(5 \%)$ & $* *$ & & & \\
\hline \multirow[t]{6}{*}{ Seedling Density ha ${ }^{-1}$} & Natural forest & $3538 \pm 390.7^{\mathbf{b}}$ & 1513.22 & 1769 & 7431 \\
\hline & Managed C. lusitanica & $5567 \pm 663.80^{c}$ & 2570.87 & 1415 & 9908 \\
\hline & $\begin{array}{l}\text { Not managed } C \text {. } \\
\text { lusitanica }\end{array}$ & $707 \pm 109.19^{a}$ & 422.87 & 354 & 1415 \\
\hline & Managed E. globules & $1462 \pm 302.76^{\mathbf{a}}$ & 1172.60 & 0 & 3185 \\
\hline & $\begin{array}{l}\text { Not managed } E \text {. } \\
\text { globules }\end{array}$ & $2524 \pm 650.55^{\mathrm{ab}}$ & 2519.56 & 0 & 8139 \\
\hline & Sig (5\%) & $* *$ & & & \\
\hline
\end{tabular}

$* *=$ significant at $1 \%$ level, $*=$ significant at $5 \%$ level, ns= not significant 


\section{Soil Seed Bank and Seedling Emergence}

Germination is one of the most critical phases in plant development. Each plant species has a specific range of environmental requirements necessary for germination. Generally studying soil seed bank status is important for future regeneration and restoration mechanisms (Mekonnen, 2016).

The mean abundance of seeds in the study area in different forest types from the above surface layer to $10 \mathrm{~cm}$ soil depth ranged from $77 \pm 19.13$ to $252 \pm 63.92$ seeds per $\mathrm{m}^{2}$ (Figure 11). The managed $C$. lusitanica had the highest density of seeds followed by adjacent natural forest, while E. globulus plantation with enrichment plantation had the least mean seed abundance (Figure 11). This might be due to the different environmental factors that affect regeneration, such as temperature, light; $\mathrm{pH}$, burial depth, and soil moisture are known to affect seed germination ( $\mathrm{Lu}$ et al., 2006). And the lowest seed density recorded in managed E.globulus was the reason behind the information obtained from focus group discussion and secondary data, the site was before converting to plantation forest it was the cultivated land and used for cropping purpose that is why the plantation forest needed enrichment planting on the left lands. Similar studies conducted at Karei Deshe in northeastern Israel farm and grazing lands previously before converting grass lands and other land uses type, the high intensity and timing of cattle grazing and cultivation changes the size and composition of the soil seed bank, even if after changing the land use type (Sternberg et al.,2003). 


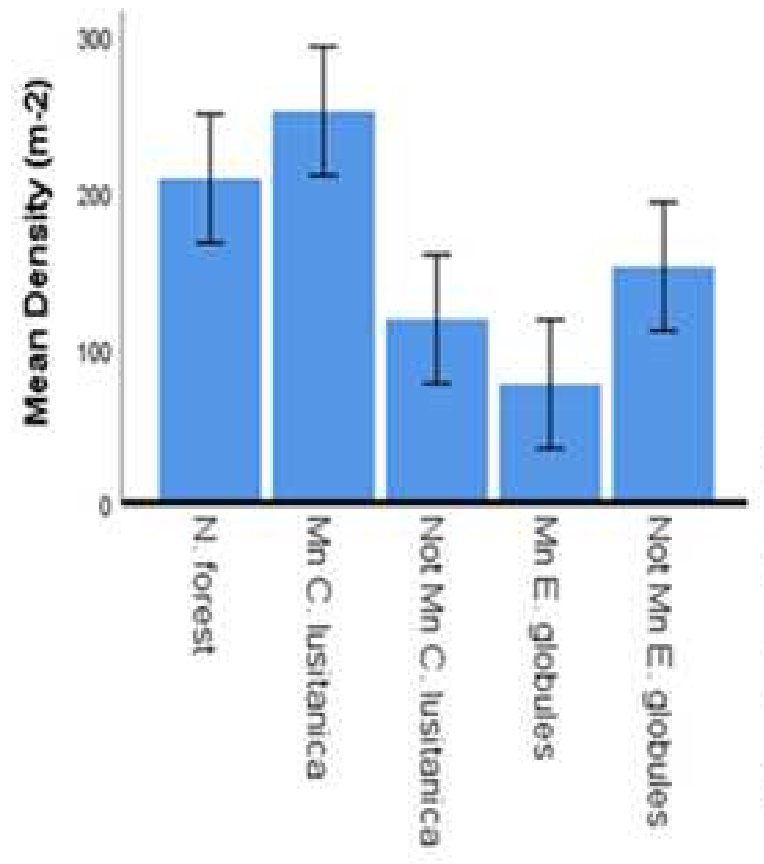

$\mathrm{N}$. forest $=$ Natural forest

$\mathrm{MnC}$. lusitanica $=$ managed C. lusitanica

Not $\mathrm{Mn}$ C. lusitanica $=$ Not managed C. lusitanica

$\mathrm{MnE}$. globules= managed E. globules

Forest types

Not MnE. globules=Not managed E. globules

Figure 10: Mean density of seeds in the soil seed bank in different forest types from above surface layer to $10 \mathrm{~cm}$ soil depth

The vertical distribution of soil seed banks in different forest types was assessed. The density of seeds in the soil showed similar vertical distribution in all forest types in a gradual decreasing along increasing soil depth (Figure 12). Similar studies done by Teketay \& Granström ( 1995) in dry Afromontane forests of Ethiopia showed density of soil seed bank decreased when the soil depth is increased. The burial depth of seeds may affect the distribution along soil depth (Lu et al., 2006). Other environmental factors such as light sensitivity, chemical inhibitors, $\mathrm{pH}$ and differences in seed longevity may affect seed distribution with depth (Eyob, 2006). Other study showed that woody species seeds tend to accumulate due to their long-lived seeds in the soil seed bank (Teketay \& Granström, 1995). However, emerging seedlings from the soil seed bank from 5-10 cm was lower compared to the above surface layer of the soil and 0-5 cm soil depth, even though emerging seedlings in different forest types were not significantly differed among each forest types $(\mathrm{F}=2386, \mathrm{p}>0.05$ (Table 10). 


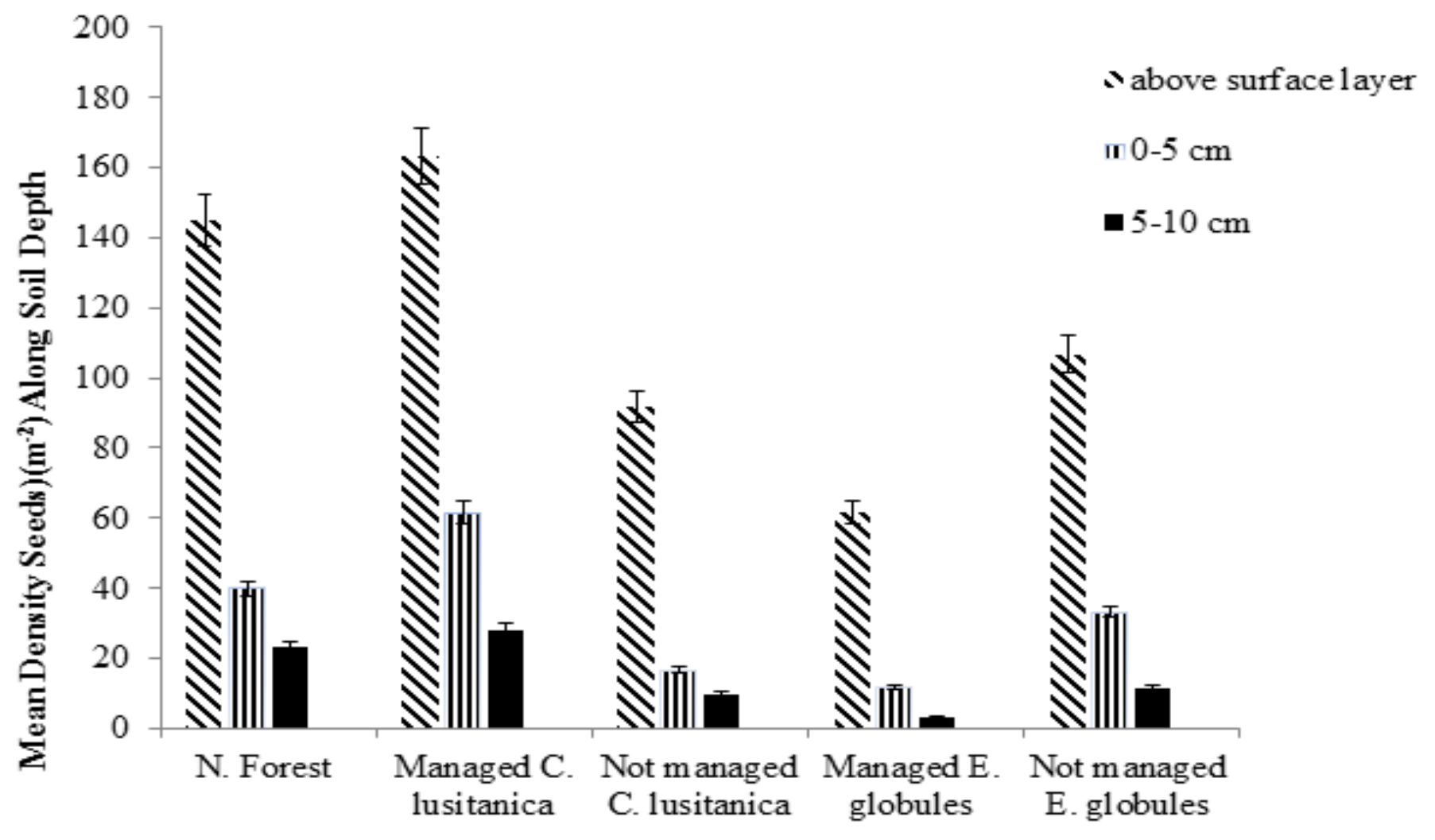

Forest types

Figure 11: Vertical distribution of viable seeds in soil depth for all forest types

The total number of species recorded in the soil seed bank both in plantation and the adjacent natural forest was 22 (twenty native and two exotic) species (Figure 13). In the natural forest higher number of species was found and followed by managed $C$. lusitanica and managed $E$. globules plantation forests. But plantation forest which had no management intervention had a low number of species (Figure 13). This is because the soil seed bank availability is affected by the presence of large indigenous trees, the distance between natural forest and dispersing agents in the plantation forest stand (Shiferaw \& Jindrich, 2012; Lemenih \& Teketay, 2004). 


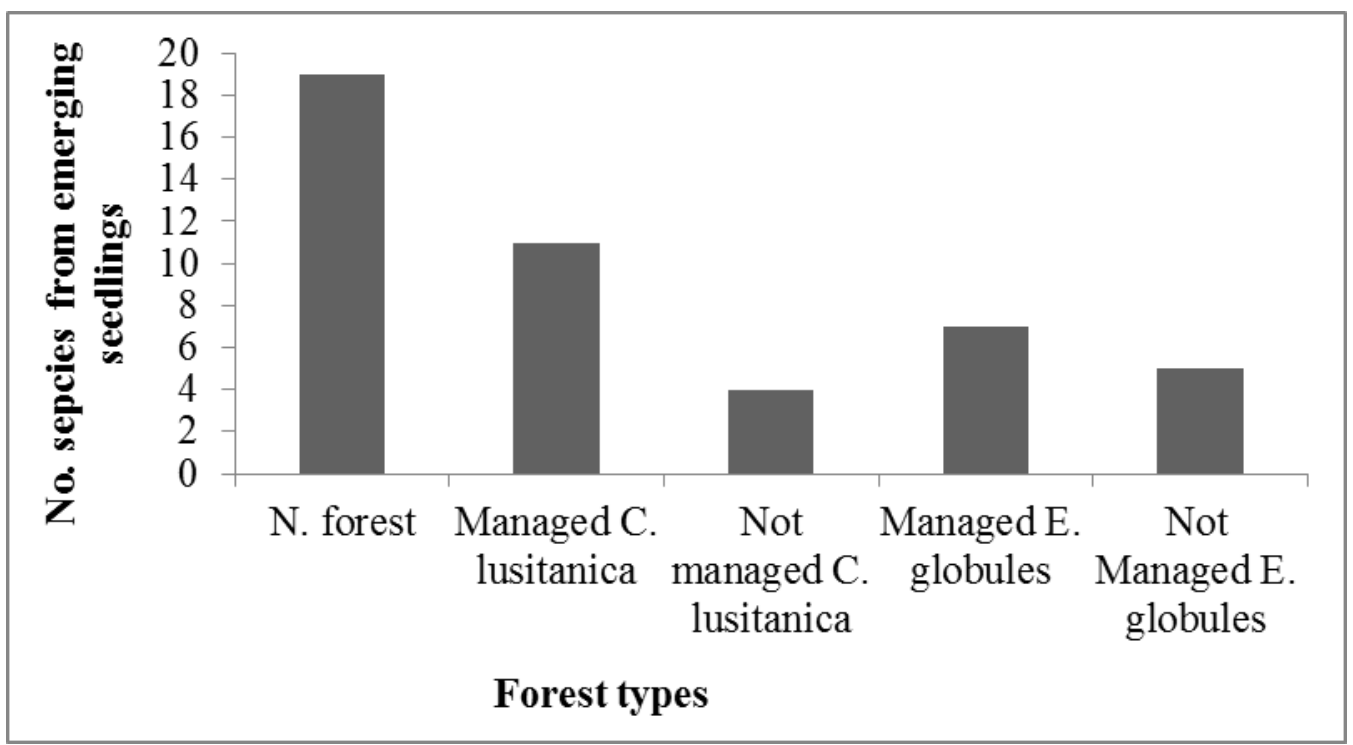

Figure 12: Emergent seedlings number of species in the soils of the different forest types

The mean densities of emerging seedlings in the above surface layer of the soil were not significant among the different forest types $(\mathrm{F}=2.493, \mathrm{p}>0.05)$ (Table 10). And the emerging seedlings from soil seed bank in the soil depth of $0-5 \mathrm{~cm}$ was minimum relative to the emerging seedlings from the above soil surface layer and the results of one way ANOVA analysis in managed E. globules was significantly lower than other forest types ( $\mathrm{F}=2.989, \mathrm{P}<0.05$ ). 
Table 10: Densities of seedlings in the soils of the different forest types along soil depth above surface $(\mathrm{F}=2.493, \mathrm{p}=0.051), 0-5 \mathrm{~cm}(\mathrm{~F}=2.98, \mathrm{p}=0.024)$ and $5-10 \mathrm{~cm}(\mathrm{~F}=2.38, \mathrm{p}=0.059, \mathrm{n}=15)$

\begin{tabular}{|c|c|c|c|c|c|}
\hline $\begin{array}{l}\text { Emerging seedling in the soil seed } \\
\text { bank per } \mathrm{m}^{2}\end{array}$ & Forest types & Mean \pm S.E & SD. & Min & $\operatorname{Max}$ \\
\hline \multirow[t]{6}{*}{ Above the surface layer of the soil } & Natural forest & $145 \pm 30.88^{\mathrm{a}}$ & 119.59 & 0 & 450 \\
\hline & Managed C. lusitanica & $163 \pm 37.70^{\mathbf{a}}$ & 146.03 & 0 & 425 \\
\hline & $\begin{array}{l}\text { Not managed } C \text {. } \\
\text { lusitanica }\end{array}$ & $91 \pm 15.74^{\mathrm{a}}$ & 60.99 & 0 & 225 \\
\hline & Managed E. globules & $61 \pm 13.77^{\mathbf{a}}$ & 53.34 & 0 & 175 \\
\hline & $\begin{array}{l}\text { Not managed } E \text {. } \\
\text { globules }\end{array}$ & $106 \pm 23.20^{\mathrm{a}}$ & 89.87 & 0 & 275 \\
\hline & Sig (5\%) & ns & & & \\
\hline \multirow[t]{6}{*}{$0-5 \mathrm{~cm}$ soil depth } & Natural forest & $40 \pm 14.80^{\mathbf{a b}}$ & 57.32 & 0 & 175 \\
\hline & Managed C. lusitanica & $61 \pm 17.40^{b}$ & 67.39 & 0 & 225 \\
\hline & $\begin{array}{l}\text { Not managed } C \text {. } \\
\text { lusitanica }\end{array}$ & $16 \pm 5.27^{\mathrm{ab}}$ & 20.41 & 0 & 50 \\
\hline & Managed E. globules & $11 \pm 5.90^{\mathrm{a}}$ & 22.88 & 0 & 75 \\
\hline & $\begin{array}{l}\text { Not managed } E \text {. } \\
\text { globules }\end{array}$ & $33 \pm 9.01^{\text {ab }}$ & 34.93 & 0 & 100 \\
\hline & Sig (5\%) & $* *$ & & & \\
\hline \multirow[t]{6}{*}{$5-10 \mathrm{~cm}$ soil depth } & Natural forest & $23 \pm 7.09^{a}$ & 27.49 & 0 & 100 \\
\hline & $\begin{array}{l}\text { Managed } \\
\text { C. lusitanica }\end{array}$ & $28 \pm 11.40^{\mathrm{a}}$ & 44.18 & 0 & 150 \\
\hline & $\begin{array}{l}\text { Not managed } \\
\text { C. lusitanica }\end{array}$ & $10 \pm 4.08^{\mathrm{a}}$ & 15.81 & 0 & 50 \\
\hline & $\begin{array}{l}\text { Managed } \\
\text { E. globules }\end{array}$ & $3 \pm 2.27^{\mathrm{a}}$ & 8.79 & 0 & 25 \\
\hline & $\begin{array}{l}\text { Not managed } \\
\text { E. globules }\end{array}$ & $11 \pm 4.13^{\mathrm{a}}$ & 15.99 & 0 & 50 \\
\hline & Sig (5\%) & ns & & & \\
\hline
\end{tabular}




\section{Species Richness, Diversity and Evenness of Soil Seed bank}

The Shannon diversity index for the diversity and evenness of soil seed bank in adjacent natural forest, managed C.lustanica and E.globulus plantation forests were good as compared to unmanaged plantation forests (Table 11). In the five forests, there was relatively higher diversity on the surface layer of soils followed by $0-5 \mathrm{~cm}$ and $5-10 \mathrm{~cm}$ soil depth. Generally, species richness decreased down the soil layers (Table 11). Similar studies in Mongolia China (Qian et al., 2016) showed species richness decreased down the soil depth.

Table 11: Soil seed bank species richness, diversity and evenness of Tarmaber plantation forest with management intervention and adjacent natural forest

\begin{tabular}{|l|l|l|l|l|}
\hline Forest type & Soil layers & $\mathrm{S}$ & $\mathrm{H}^{\prime}$ & $\mathrm{E}$ \\
\hline \multirow{3}{*}{ Natural forest } & Above litter layer & 19 & 2.59 & 0.88 \\
\cline { 2 - 5 } & $0-5 \mathrm{~cm}$ & 11 & 2.22 & 0.93 \\
\hline \multirow{5}{*}{ Managed C.lustanica } & $5-10 \mathrm{~cm}$ & 7 & 1.57 & 0.81 \\
\cline { 2 - 5 } & Above litter layer & 9 & 1.47 & 0.67 \\
\cline { 2 - 5 } & $0-5 \mathrm{~cm}$ & 7 & 1.16 & 0.60 \\
\cline { 2 - 5 } & $5-10 \mathrm{~cm}$ & 5 & 1.3 & 0.81 \\
\hline \multirow{5}{*}{ Managed E.globulus } & Above litter layer & 7 & 1.42 & 0.73 \\
\cline { 2 - 5 } & $0-5 \mathrm{~cm}$ & 4 & 1.15 & 0.83 \\
\cline { 2 - 5 } & $5-10 \mathrm{~cm}$ & 1 & 0 & 0.00 \\
\hline \multirow{5}{*}{ Not managed E.globulus } & Above litter layer & 4 & 0.62 & 0.45 \\
\cline { 2 - 5 } & $0-5 \mathrm{~cm}$ & 1 & 0 & 0.00 \\
\cline { 2 - 5 } & $5-10 \mathrm{~cm}$ & 1 & 0 & 0.00 \\
\cline { 2 - 5 } & Above litter layer & 5 & 1.14 & 0.71 \\
\cline { 2 - 5 } & $5-5 \mathrm{~cm}$ & 4 & 1.14 & 0.82 \\
\hline
\end{tabular}




\section{Similarity between Soil Seed Bank and Aboveground Flora}

The similarity between the soil seed bank and aboveground flora was ranged from similarity index values from 0.230 for not managed $C$. lusitanica plantation forest to 0.633 for natural forest (Table 13). Totally twenty two species (20 native and 2 exotic) woody species out of 51 species (Allophylus abyssinicus, Bersama abyssinica, Cupressus lusitanica, Discopodium penninervum, Dovyalis abyssinica, Eucalyptus globulus, Embelia schimperi, Erica arborea, Galiniera saxifrage, Juniperus procera, Laggera pterodonata, Maesa lanceolata, Maytenus arbutifolia, Morus mesozygia, Olea africana, Phytolacca dodecandra, Prunus africa, Rhnmnus prinoides, Rumex nervosus, solanum dasyphyllum, Vernonia amygdalina and Vernonia auriculifera) were represented both in the aboveground vegetation and in the soil seed bank. This implies that the soil seed bank contributed for the aboveground flora or vice versa (Looney \& Gibson, 1995). This is because, most woody species do not accumulate seeds in the soil and only few woody species tend to produce recalcitrant seeds (Teketay \& Granström, 1995).

Table 12: Similarity between soil seed bank and above ground flora (* the lowest similarity, ** the highest similarity)

\begin{tabular}{|l|l|l|l|l|}
\hline Forest types & $\begin{array}{l}\text { Common species } \\
\text { both in above } \\
\text { ground flora \& soil } \\
\text { seed bank }\end{array}$ & $\begin{array}{l}\text { Species } \\
\text { exclusive to } \\
\text { aboveground } \\
\text { flora }\end{array}$ & $\begin{array}{l}\text { Species } \\
\text { exclusive to } \\
\text { soil seed bank }\end{array}$ & $\begin{array}{l}\text { Sorenson's } \\
\text { coefficient } \\
\text { similarity values }\end{array}$ \\
\hline Natural forest & 19 & 22 & 0 & $0.633^{* *}$ \\
\hline Managed $C$. lusitanica & 9 & 18 & 2 & 0.473 \\
\hline Not managed C. lusitanica & 3 & 19 & 1 & $0.230^{*}$ \\
\hline Managed E. globules & 6 & 16 & 1 & 0.413 \\
\hline Not managed E. globules & 4 & 9 & 1 & 0.444 \\
\hline
\end{tabular}

The similarity between the different soil layers was also important. Generally, the similarity between the above surface layer and 0-5 $\mathrm{cm}$ and 5-10 soil depth was relatively higher (Table 13) however; unmanaged plantations and managed E. globules plantation forest had low similarity in some soil depth layers. 
Table 13: Sorenson's coefficient of similarity in species composition of soil seed banks across soil depth layers in different forest types

\begin{tabular}{|c|c|c|c|c|}
\hline Forest types & $\begin{array}{l}\text { Soil seed bank } \\
\text { collection soil layers }\end{array}$ & $\begin{array}{l}\text { Soil surface } \\
\text { layer }\end{array}$ & $0-5 \mathrm{~cm}$ & $5-10 \mathrm{~cm}$ \\
\hline \multirow[t]{3}{*}{ Natural forest } & $\begin{array}{l}\text { Above soil surface } \\
\text { layer }\end{array}$ & & 0.733 & 0.538 \\
\hline & $0-5 \mathrm{~cm}$ & & & 0.777 \\
\hline & $5-10 \mathrm{~cm}$ & & & \\
\hline \multirow[t]{4}{*}{$\begin{array}{l}\text { Managed } \\
\text { C.lusitanica }\end{array}$} & & $\begin{array}{l}\text { Above soil } \\
\text { surface layer }\end{array}$ & $0-5 \mathrm{~cm}$ & $5-10 \mathrm{~cm}$ \\
\hline & $\begin{array}{l}\text { Above soil surface } \\
\text { layer }\end{array}$ & & 0.750 & 0.714 \\
\hline & $0-5 \mathrm{~cm}$ & & & 0.666 \\
\hline & $5-10 \mathrm{~cm}$ & & & \\
\hline \multirow[t]{4}{*}{$\begin{array}{l}\text { Not managed } C \text {. } \\
\text { lusitanica }\end{array}$} & & $\begin{array}{l}\text { Above soil } \\
\text { surface layer }\end{array}$ & $0-5 \mathrm{~cm}$ & $5-10 \mathrm{~cm}$ \\
\hline & $\begin{array}{l}\text { Above soil surface } \\
\text { layer }\end{array}$ & & 0.400 & 0.400 \\
\hline & $0-5 \mathrm{~cm}$ & & & \\
\hline & $5-10 \mathrm{~cm}$ & & & \\
\hline \multirow[t]{4}{*}{$\begin{array}{l}\text { Managed } \\
\text { E. globules }\end{array}$} & & $\begin{array}{l}\text { Above soil } \\
\text { surface layer }\end{array}$ & $0-5 \mathrm{~cm}$ & $5-10 \mathrm{~cm}$ \\
\hline & $\begin{array}{l}\text { Above soil surface } \\
\text { layer }\end{array}$ & & 0.600 & 0.250 \\
\hline & $0-5 \mathrm{~cm}$ & & & 0.400 \\
\hline & $5-10 \mathrm{~cm}$ & & & \\
\hline \multirow[t]{4}{*}{$\begin{array}{l}\text { Not managed } \\
\text { E. globules }\end{array}$} & & $\begin{array}{l}\text { Above soil } \\
\text { surface layer }\end{array}$ & $0-5 \mathrm{~cm}$ & $5-10 \mathrm{~cm}$ \\
\hline & $\begin{array}{l}\text { Above soil surface } \\
\text { layer }\end{array}$ & & 0.888 & 0.750 \\
\hline & $0-5 \mathrm{~cm}$ & & & 0.857 \\
\hline & $5-10 \mathrm{~cm}$ & & & \\
\hline
\end{tabular}

\section{CONCLUSION}

The plantations studied were mainly monocultures and it is suggested that management intervention could possibly improve the regeneration of indigenous tree species.

Different species of exotic tree plantations with management intervention showed variability in their understory woody species regeneration. In comparison managed plantations and the natural 
forests to unmanaged plantations stands the exotic tree plantations had limited effectiveness in facilitating regeneration of indigenous woody vegetation.

The managed $C$. lusitanica (pruning of branches) creates a good opportunity for light penetration found to be effective in facilitating woody species regeneration as compared to the unmanaged plantations forests.

The different species of plantation forest varied in woody species composition, diversity and soil attributes showing that the over-story species affected regeneration. The various factors that influence regeneration such as canopy cover, limitation of seed dispersal agents, seed source natural forests near to plantation forest and soil seed bank limitation and management intervention can be linked to the species of tree regeneration. Enrichment planting of indigenous tree species in plantations would enhance conservation efforts as well as providing alternative sources of forest resources.

The soil seed bank of the studied sites was dominated by 20 native and 2 exotic woody species and this is the inverse of the understory vegetation which was dominated by woody vegetation.

The proximity of natural forests to plantations forests has been shown to enhance the floristic diversity in plantations and could perhaps enhance the viability of the woody species populations in the plantation forests.

Plantations can play an important role in restoring the productivity, ecosystem stability, and biodiversity of degraded tropical lands as well as providing economically and socially valued forest products and services. Through careful selection of appropriate management, the negative effects of the plantations can be offset while facilitating indigenous forest regeneration. The local people perception about plantation forest expansion in environmental and ecological issues was positive concerning soil conservation, biodiversity, water flow and rehabilitation

\section{RECOMMENDATIONS}

The inclusion pruning and enrichment planting of species in plantations as well as natural forest of indigenous tree species into further studies on regeneration could aid in determining the most suitable reforestation method that would provide greater ecological gains and improve productivity. 
The use of enrichment planting to expand the area covered by the indigenous forest has been noted within selected areas in the Tarmaber plantation forest to increase indigenous forest cover and to utilize the left lands from plantations. Studies to determine the effectiveness of enrichment planting in enhancing woody species regeneration and diversity would enhance conservation benefits.

This study could be improved through the inclusion of a comparison with a secondary forest in order to determine the understory regeneration status in comparison to natural forests and plantations. Studies that include comparisons with plantations of indigenous woody species would also provide valuable information on the effectiveness of indigenous versus exotic tree plantations.

The link between natural forests and plantations implies that the conservation of the natural forest stands that are the only indigenous woody species refuges left in many parts of Ethiopia should be given high priority and importance.

To know clear information how many years the soil seed bank found in the soil and it is better to study soil seed bank treatment methods for germination.

It is better doing detail the dispersing agents of the seeds in the study area.

Training, filled observation should be given for farmers and scientific stake holders on the management effect on regeneration, density and diversity composition under the canopy of plantation forest. 


\section{References}

Abrham, A., Mulugeta, L., Georg, G., Raf, A., Demel, T., \& Gerhard, G. (2011). Status of Native Woody Species Diversity and Soil Characteristics in an Exclosure and in Plantations of Eucalyptus globulus and Cupressus lusitanica in Northern Ethiopia. Mountain Research and Development, 31(2), 144-152.

Ajayi, S., \& Obi, R. L. (2016). Tree Species Composition, Structure and Importance Value Index ( IVI ) of Okwangwo Division, Cross River National Park, Nigeria. International Journal of Science and Research, 5(12), 85-93.

Abyot, D., Teshome, S., Ensermu, K., \& Abiyou, T. (2014). Diversity, Structure and Regeneration Status of the Woodland and Riverine Vegetation of Sire Beggo in Gololcha District , Eastern Ethiopia. Momona Ethiopian Journal of Science, 1, 70-96.

AFE (Amhara Forest Enterprise). (2017). Debre birhan branch Forest management Plan.

Alelign, A., Teketay, D., Yemshaw, Y., \& Edwards, S.U.E. (2007). Diversity and status of regeneration of woody plants on the peninsula of Zegie, northwestern Ethiopia. Tropical Ecology, 48(1), 37-49.

Alemayehu, W. (2002). Opportunities, constraints and prospects of the Ethiopian Orthodox Tewahido Churches in conserving forest resources : the case of churches in south Gonder, northern Ethiopia MSc Thesis in Swedish University of Agricultural Sciences, 37-55

Ayanaw, A., \& Gemedo, D. (2018). Woody Species Diversity, Structure, and Regeneration Status of Yemrehane Kirstos Church Forest of Lasta Woreda, North Wollo Zone, Amhara Region, Ethiopia. International Journal of Forestry Research, 4-7.

Aynekulu, B. (2011). Forest diversity in fragmented landscapes of northern Ethiopia and implications for conservation. Rheinische Friedrich-Wilhelms-Universität Bonn.

Balliu, A., Marsic, N.K., \& Gruda, N. (2017). Seedling production.

Bauhaus, J., \& Schmerbeck, J. (2010). Silvicultural Options to Enhance and Use Forest Plantation Biodiversity. EARTH Ecosystem Goods, 3569, 96-127.

Becerra, P.I., Catford, J.A., Inderjit, Luce McLeod, M., Andonian, K., Aschehoug, E.T., Callaway, R.M. (2018). Inhibitory effects of Eucalyptus globulus on understorey plant growth and species richness are greater in non-native regions. Global Ecology and 
Biogeography, 27(1), 68-76.

Bernes, C., Gunnar, J.B., Junninen, K., Lõhmus, A., Macdonald, E., Müller, J., \& Sandström, J. (2014). What is the impact of active management on biodiversity in forests set aside for conservation or restoration? A systematic review protocol. Environmental Evidence, 22(3), $1-9$.

Carnus, J.M., Parrotta, J., Brockerhoff, E., Arbez, M., Jactel, H., Kremer, A., Walters, B. (2006). Planted forests and biodiversity. Journal of Forestry, 104(2), 65-77.

Central Statistics Agency (CSA, 2007).

Chao, A., Chazdon, R., Colwell, R., \& Shen, T. (2005). A new statistical approach for assessing compositional similarity based on incidence and abundance data. Ecology Letters, 8, 148159.

Colin, C., \& Lauren, C. (1996). Exotic tree plantations and the regeneration of natural forests in Kibale National Park, Uganda. Biological Conservation, (3), 253-257.

Dupuy, J.M., \& Chazdon, R.L. (2006). Effects of vegetation cover on seedling and sapling dynamics in secondary tropical wet forests in Costa Rica. Journal of Tropical Ecology, 22, $65-76$.

EEPA (Ethiopian Environmental Protection Authority) (2013). Federal Democratic Republic of Ethiopia’s Climate Resilient Green Economy.

EIAR (Ethiopia Impact Assessment Report) (2011). Federal democratic republic of Ethiopia consultancy service for detailed engineering design, document Debre birhan - Ankober road project environmental impact assessment report.

Edwards, S., Tadesse, M., Demissew, S., \& Hedberg, I. (2000). Flora of Ethiopia \& Eritrea Volume 2, Part 1 (2nd ed.). Addis Ababa, Ethiopia.

Ermias.D (2011). Natural Database for Africa(NDA ) On CD-ROM Version 2.0

Eslami, A., Karimi, B., Payam, H., \& Derakhshan, O.K. (2011). Investigation of the structure and distribution diameter classes models in beech forests of Northern Iran. African Journal of Agricultural Research, 6(10), 2157-2165.

Esmailzadeh, O., Hosseini, S.M., \& Tabari, M. (2011). Relationship Between Soil Seed Bank and Above-ground Vegetation of a Mixed-deciduous Temperate Forest in Northern Iran. Journal 
of Agricultural Science and Technology, (13), 411-424

Eyob, T. (2006). Soil Seed Bank Study and Natural Regeneration Assessment of Woody Species in Dodola Dry Afromontane Forest, Bale Mountains MSc Thesis at Addis Ababa University.

Feyera, S., Beck, E., \& Lüttge, U. (2002). Exotic trees as nurse-trees for the regeneration of natural tropical forests. Trees, 16(4-5), 245-249.

Feyera, S., \& Demel, T. (2001). Regeneration of indigenous woody species under the canopies of tree plantations in Central Ethiopia. Tropical Ecology, 42(2), 175-185.

Fikadu, E., Melesse, M., \& Wendawek, A. (2014). Floristic composition, diversity and vegetation structure of woody plant communities in Boda dry evergreen Montane Forest, West Showa, Ethiopia. International Journal of Biodiversity and Conservation, 6(5), 382-391.

Fisaha, G., Hundera, K., \& Dalle, G. (2013). Woody plants' diversity, structural analysis and regeneration status of Wof Washa natural forest, North-east Ethiopia. African Journal of Ecology, 51(4), 599-608.

Getachew, M., \& Biruk, A. (2014). Status of native woody species regeneration in the plantation stands of Yeraba priority state forest, Amhara Region, Ethiopia. Journal of Natural Sciences Research, 4(16), 91-103.

Gillison, A., \& Brewer, K. (2014). The Use of Gradient Directed Transects or Gradsects in Natural Resource Surveys. Journal of Environmental Management, 20, 103-127.

Gilman, A.C., Letcher, S.G., Fincher, R., Perez, A.I., Madell, T.W., Finkelstein, A.L., \& Corrales-Araya, F. (2016). Recovery of floristic diversity and basal area in natural forest regeneration and planted plots in a Costa Rican wet forest. Biotropica, 48(6), 798-808.

Gomaa, N. (2015). Soil seed bank in different habitats of the Eastern Desert of Egypt. Saudi Journal of Biological Sciences, 19(2), 211-220.

Hall, B. (2009). Data Sheets on Species Undergoing Genetic Impoverishment Juniperus Procera Hochst. Ex Endl. Morogoro, Tanzania.

Hökkä, H., Alenius, V., \& Penttilä, T. (1997). Individual-tree Basal Area Growth Models for Scots Pine, Pubescent Birch and Norway Spruce on Drained Peatlands in Finland. Silva Fennica, 31(2), 161-178. 
Hundera, K. (2011). Status of indigenous tree species regeneration under exotic plantations in Belete forest, South West Ethiopia. Ethiopian Journal of Education and Sciences, 5(2), 1926.

Jennifer, S., \& Alistair, S. (2013). The benefits and hazards of exploiting vegetative regeneration for forest conservation management in a warming world, 86, 503-513.

Karlsson, L. (2013). Silvicultural regimes and early biomass thinning in young, dense pine stands. Doctoral Thesis Swedish University of Agricultural Sciences.

Kerr, G. (2015). The use of silvicultural systems to enhance the biological diversity of plantation forests in Britain.

Kent, M. and Coker, P. (1992). Vegetation Description and Analysis. A practical approach. John Wiley and Sons, New York, 363.

Khaine, I., Woo, S.Y., Kang, H., Kwak, M., Sun, M., Youh, H., Kim, J. (2017). Species Diversity, Stand Structure, and Species Distribution across a Precipitation Gradient in Tropical Forests in Myanmar. Forests, 8(282), 1-15.

Lawson, D., \& Henrik, J.J. (2006). The species-area relationship and evolution. Journal of Theoretical Biology, 241, 590-600.

Lemenih, M., \& Teketay, D. (2004). Restoration of Native Forest Flora in the Degraded Highlands of Ethiopia: Constraints and Opportunities. Ethiopian Journal of Science, 27(1), 75-90.

Linares, J.C., Carreira, J.A., \& Ochoa, V. (2011). Human impacts drive forest structure and diversity. Insights from Mediterranean mountain forest dominated by Abies pinsapo ( Boiss). European Journal of Forest Research, 25-40

Looney, P., \& Gibson, D. (1995). The Relationship between the Soil Seed Bank and AboveGround Vegetation of a Coastal Barrier Island. Journal of Vegetation Science, 6(6), 825836.

Lu, P., Sang, W., \& Ma, K. (2006). Effects of environmental factors on germination and emergence of Crofton weed (Eupatorium adenophorum). Weed Science, 54, 452-457.

Maranon, T. (1998). Soil seed bank and community dynamics in an annual-dominated Mediterranean salt-marsh. Journal of Vegetation Science 9, 371-378. 
Margalef, R.(1958). Information theory in Ecology, Genetic and Systematic, 3, 36-71.

Markus, K. (2012). Global tree plantation expansion review (3).

Mekonnen, A. (2016). Soil Seed Bank and Natural Regeneration of Trees. Journal of Sustainable Development, 9(2), 73.

Midgley, J.J., \& Niklas, K. (2004). Does disturbance prevent total basal area and biomass in indigenous forests from being at equilibrium with the local environment? Journal of Tropical Ecology, 20, 595-597.

Millet, J., Tran, N., Ngoc, N ., Tran, T., \& Prat, D. (2013). Enrichment planting of native species for biodiversity conservation in a logged tree plantation in Vietnam. New Forests, 44, 369383.

Minore, D., \& Laacke, R. (2001). Natural Regeneration, 11, 258-283.

Mulugeta, W. A. (2017). Assessing the value added of forest ecosystems conservation and plant species diversity in four key biodiversity areas in Ethiopia. Bees for Development of Ethiopia, (2753).

Muluneh, M. (2011). Eucalyptus plantations in the highlands of Ethiopia revisited: A comparison of soil nutrient status after the first coppicing. University of Natural Resources and Applied Life Sciences Vienna.

Nagaraja, B. C., Niki, M., \& Somashekara, R. (2011). Regeneration of native woody species under plantations in Kudremukh National Park, Western Ghats of South India. International Journal of Biodiversity Science, Ecosystem Services and Management, 7(2), 77-83.

Nenninger, A., Kateb, H.El, Fetene, M., \& Mosandl, R. (2012). Silviculture Contributions Towards Sustainable Management of Plantation Forests in the Highlands of Ethiopia, 188.

Omoro, L.M.A., \& Luukkanen, O. (2011). Native Tree Species Regeneration and Diversity in the Mountain Cloud Forests of East Africa. Biodiversity Loss in a Changing Planet, 241-256.

Pande, P.K., Bisht, A.P.S., \& Sharma S.C. 1988. Comparative vegetation analysis of some plantation ecosystems. Indian Forester, 114, 379-389

Parrota, J.A. (1992). The role of plantations forests in rehabilitating degraded tropical ecosystems. Agriculture, Ecosystem and Environment, 41, 115-133.

Peet R.K., (1974). The measurement of species diversity. Annual review of ecology and 
systematic, 5, 285-307.

Peters, C.M. (1996). The ecology and management of non-timber forest resources. World Bank Technical paper 322.

Petit, B., \& Montagnini, F. (2006). Growth in pure and mixed plantations of tree species used in reforesting rural areas of the humid region of Costa Rica, Central America. Forest Ecology and Management, 233, 338-343.

Pichette, P.R. and Gillespie. L. (1999). Terrestrial vegetation biodiversity monitoring protocols. Ecological monitoring and assessment network occasional paper series. Report No. 9. Burlington, onterio, Canada. 123-124.

Pielou, E.C., (1966). The measurement of diversity in different types of biological collections. Statistical research service, Canada department of agriculture, Ottawa, Ontario, Canada. Theoret. Boil., 13,131-144.

Pima, N.E. (2015). Growth Performance, Water Use and Wood Properties of Eucalypt Clones in Tanzania. Sokoine University of Agriculture, Tanzania.

Qiaoying, Z., Yunchun, Z., Yirdaw, E., Peng, L., Shaoliang, Y., \& Ning, W. (2006). Species diversity based on vertical structure as indicators of artificial restoration for coniferous forests in Southwest China. Wuhan University Journal of Natural Sciences, 8(4), 2006.

Qian, J., Liu, Z., Hatier, J. B., \& Liu, B. (2016). The vertical distribution of soil seed bank and its restoration implication in an active sand dune of northeastern Mongolia, China. Land Degradation \& Development, 27, 305-315.

Savadogo, P., Sanou, L., Dayamba, S., Bognounou, F., \& Thiombiano, A. (2016). Relationships between soil seed banks and above-ground vegetation along a disturbance gradient in the $\mathrm{W}$ Park trans-boundary biosphere reserve, West Africa. Journal of Plant Ecology Advance, 234.

Scheiner, S.M., Cox, S B., Willig, M., Mittelbach, G.G., Osenberg, C., \& Kaspari, M. (2000). Species richness, species- area curves and Simpson's paradox. Evolutionary Ecology Research, 2, 791-802.

Sean, P.H., \& Robert, I.G. (2003). The effect of a teak (Tectona grandis) plantation on the establishment of native species in an abandoned pasture in Costa Rica. Forest Ecology and 
Management, 176(1-3), 497-507.

Sekaleli, T. S. . (2012). The Impact of Eucalypts Plantation on Soil Moisture and Ground Vegetation Cover at St. Michaels in the Roma valley, Lesotho, 1-19.

Shiferaw, A. (2006). Regeneration of Indigenous Woody Plants, Status of Soil Fertility and Quality of Coffee Found in an Eucalyptus grandis Plantation and the adjacent Natural Forest in Southwestern Ethiopia, MSc Thesis in Addis Ababa University, 28-44

Shiferaw, A., \& Jindrich, P. (2012). Native Woody Plants Diversity and Density under Eucalyptus camaldulensis Plantation, in Gibie Valley, South Western Ethiopia. Open Journal of Forestry, 2(4), 232-239.

Shiferaw, A., Jindrich, P., Josef, U., \& Jiř́, K. (2015). Pure and Mixed Plantations of Eucalyptus camaldulensis and Cupressus lusitanica: Their Growth Interactions and Effect on Diversity and Density of Undergrowth Woody Plants in Relation to Light. Open Journal of Forestry, 5, 375-386.

Shiferaw, A., \& Tadesse, W. (2009). A comparative assessment on regeneration status of indigenous woody plants in Eucalyptus grandis plantation and adjacent natural forest. Journal of Forestry Research, 20(1), 32-35.

Sternberg, M., Mario, G., Perevolotsky, A., \& Jaime, K. (2003). Effects of grazing on soil seed bank dynamics: An approach with functional groups. Journal of Vegetation Science, 14, 375-386.

Tadele, D. (2004). Growth and Establishment of Seedlings of Indigenous Species inside Plantations and the Adjacent Natural Forest in MSc Thesis at Addis Ababa University.

Tadele, D., \& Fetene, M. (2013). Photosynthetic Responses of Seedlings of two Indigenous Plants inside Exotic Tree Plantations and adjacent Natural Forest in Munessa-Shashemene Forest, Southern Ethiopia. Momona Ethiopian Journal of Science, 5(2), 3-14.

Tadele, D., Lulekal, E., Damtie, D., \& Assefa, A. (2014). Floristic diversity and regeneration status of woody plants in Zengena Forest, a remnant montane forest patch in north western Ethiopia. Journal of Forestry Research, 25(2).

Teketay, D. (2005). Seed and regeneration ecology in dry Afromontane forests of Ethiopia:Forest disturbances and succession. Tropical Ecology, 46(1), 29-44. 
Teketay, D., \& Granström, A. (1995). Soil seed banks in dry Afromontane forests of Ethiopia. Journal of Vegetation Science, 6, 777-786.

Tilashwork, C. A. (2009). The Effect of Eucalyptus on Crop Productivity, And Soil Properties in the Koga Watershed, Western Amhara Region, Ethiopia MSc Thesis in Cornell University,6-27

Tulod, A., Casas, J., Marin, R. A., \& Ejoc, J. B. (2017). Diversity of native woody regeneration in exotic tree plantations and natural forest in Southern Philippines. Forest Science and Technology, 13(1), 31-40.

TWAO (Tarmaber woreda Agricultural office). (2018). Tarmaber Woreda annual Socioeconomic Survey.

Varga, A., Ódor, P., Molnár, Z., \& Bölöni, J. (2015). The history and natural regeneration of a secondary oak-beech woodland on a former wood-pasture in Hungary. Acta Societatis Botanicorum Poloniae, 84(2), 215-225.

Wagner, M., Poschlod, P., \& Setchfield, R.P. (2003). Soil seed bank in managed and abandoned semi-natural meadows in Soomaa National Park , Estonia. Annales Botanici Fennici, 40, 87100.

Williams, R. A. (2015). Mitigating Biodiversity Concerns in Eucalyptus Plantations Located in South China. Journal of Biosciences and Medicines, 3, 1-8.

Yineger, H., Kelbessa, E., Bekele, T., \& Lulekal, E. (2008). Floristic Composition and Structure of the Dry Afromontane Forest at Bale Mountains National Park, Ethiopia. SINET Ethiopian Journal of Science, 31(2), 103-120.

Yvette, K., \& David, E. (2002). Roads as edges: Effects on vegetation in forested landscapes. Forest Science, 48(2), 381-390. 


\section{Figures}

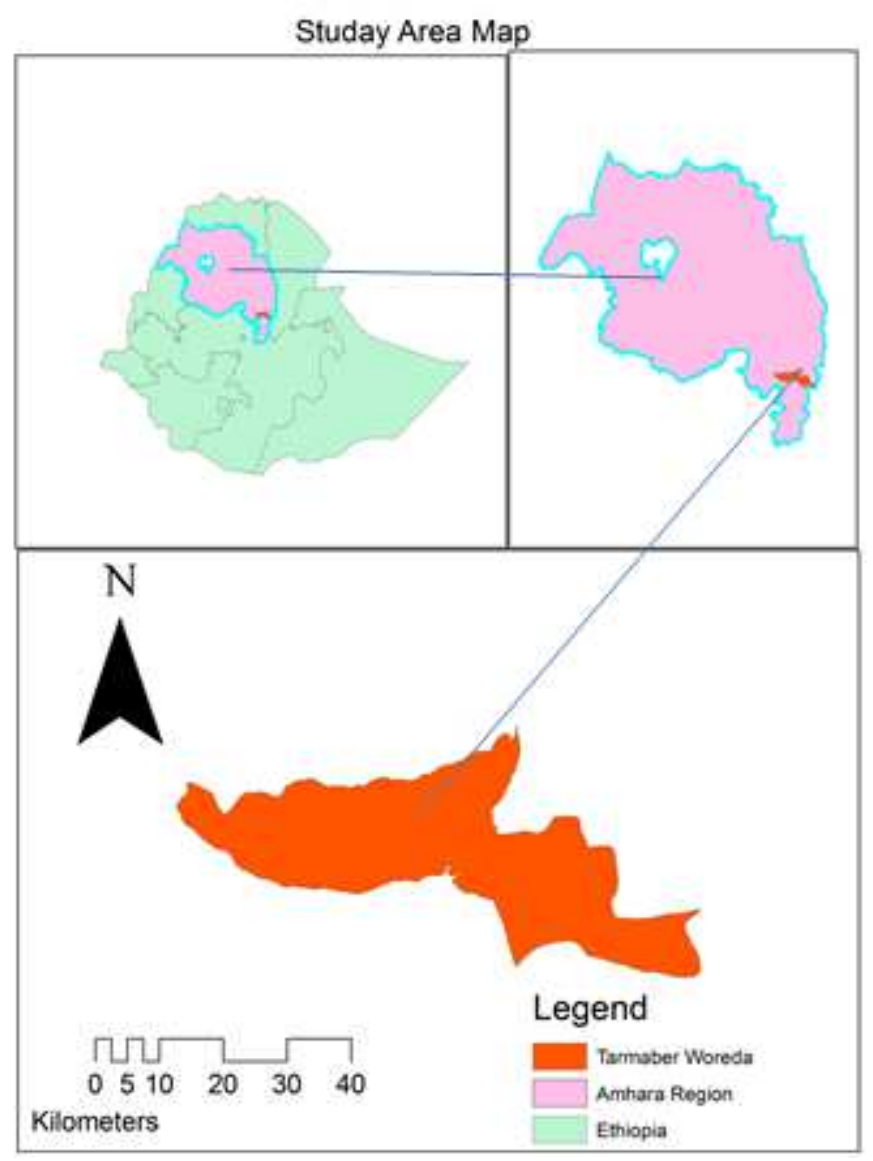

\section{Figure 1}

Map of Study Area Note: The designations employed and the presentation of the material on this map do not imply the expression of any opinion whatsoever on the part of Research Square concerning the legal status of any country, territory, city or area or of its authorities, or concerning the delimitation of its frontiers or boundaries. This map has been provided by the authors. 


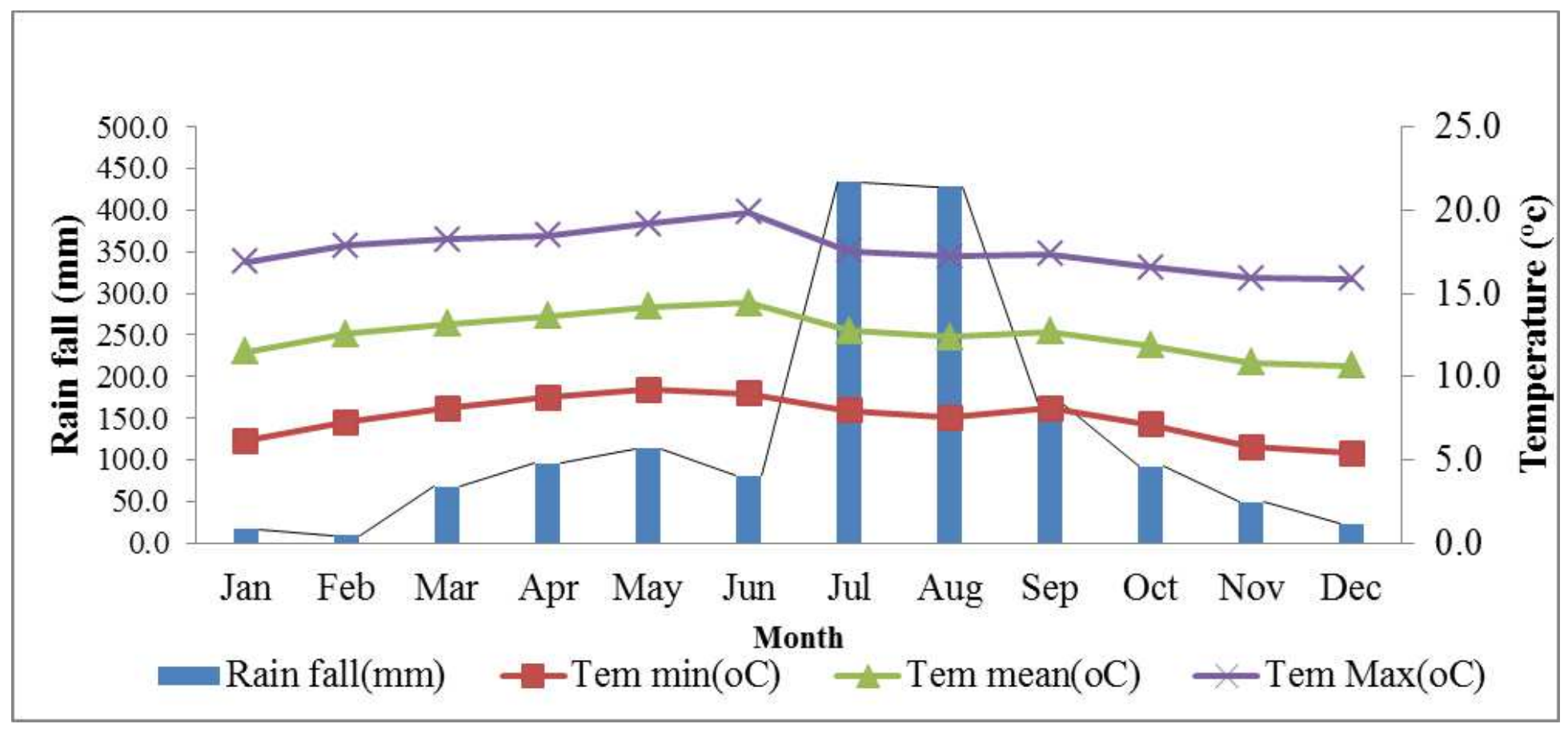

Figure 2

Long term average monthly rain fall, minimum, maximum and average temperature from 1994-2018 (Andit Tid metrological station), and $8 \mathrm{~km}$ far from the Tarmaber plantation forest) 


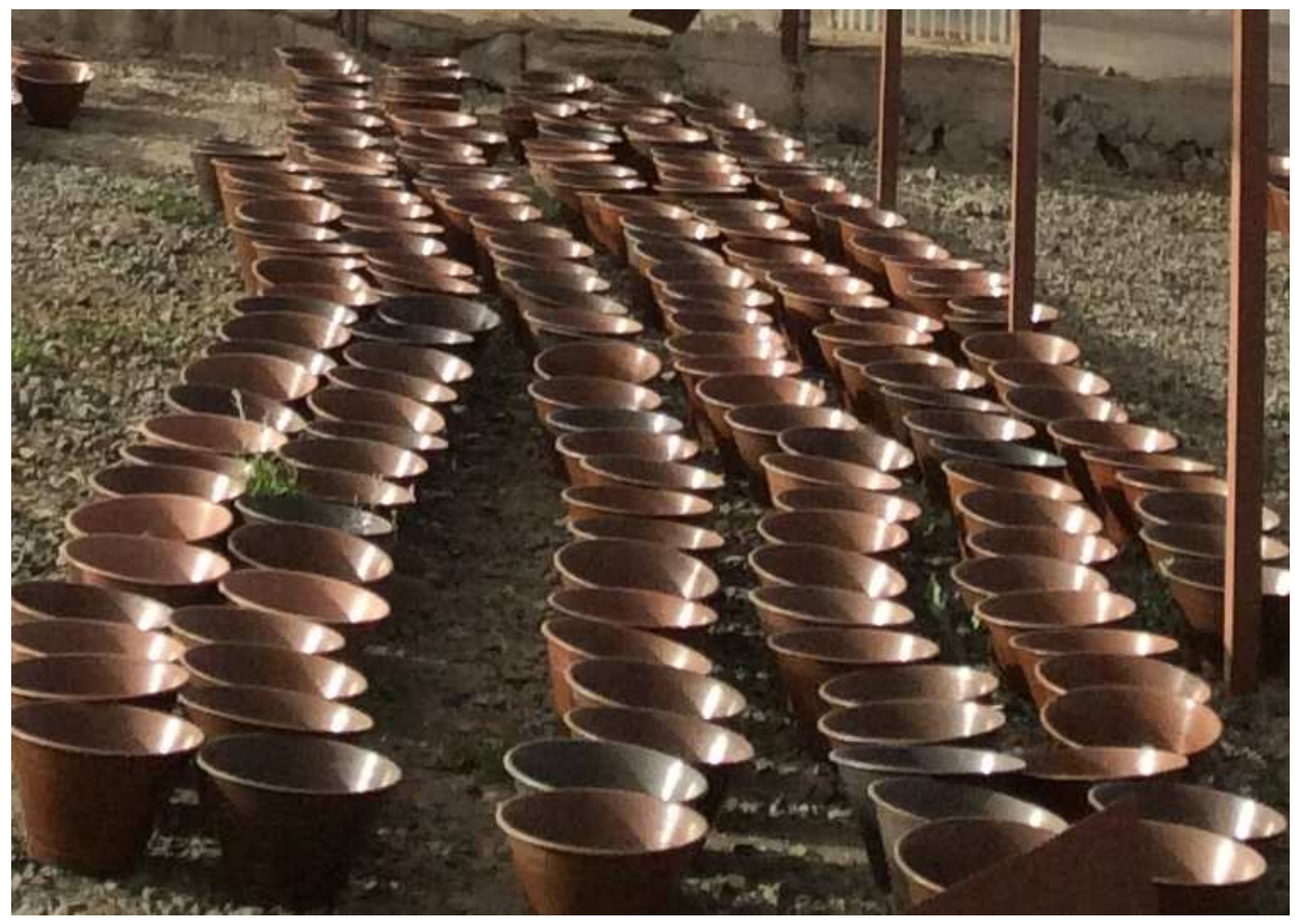

Figure 3

Growing seeds from the soil seed bank (inside the glass house) 


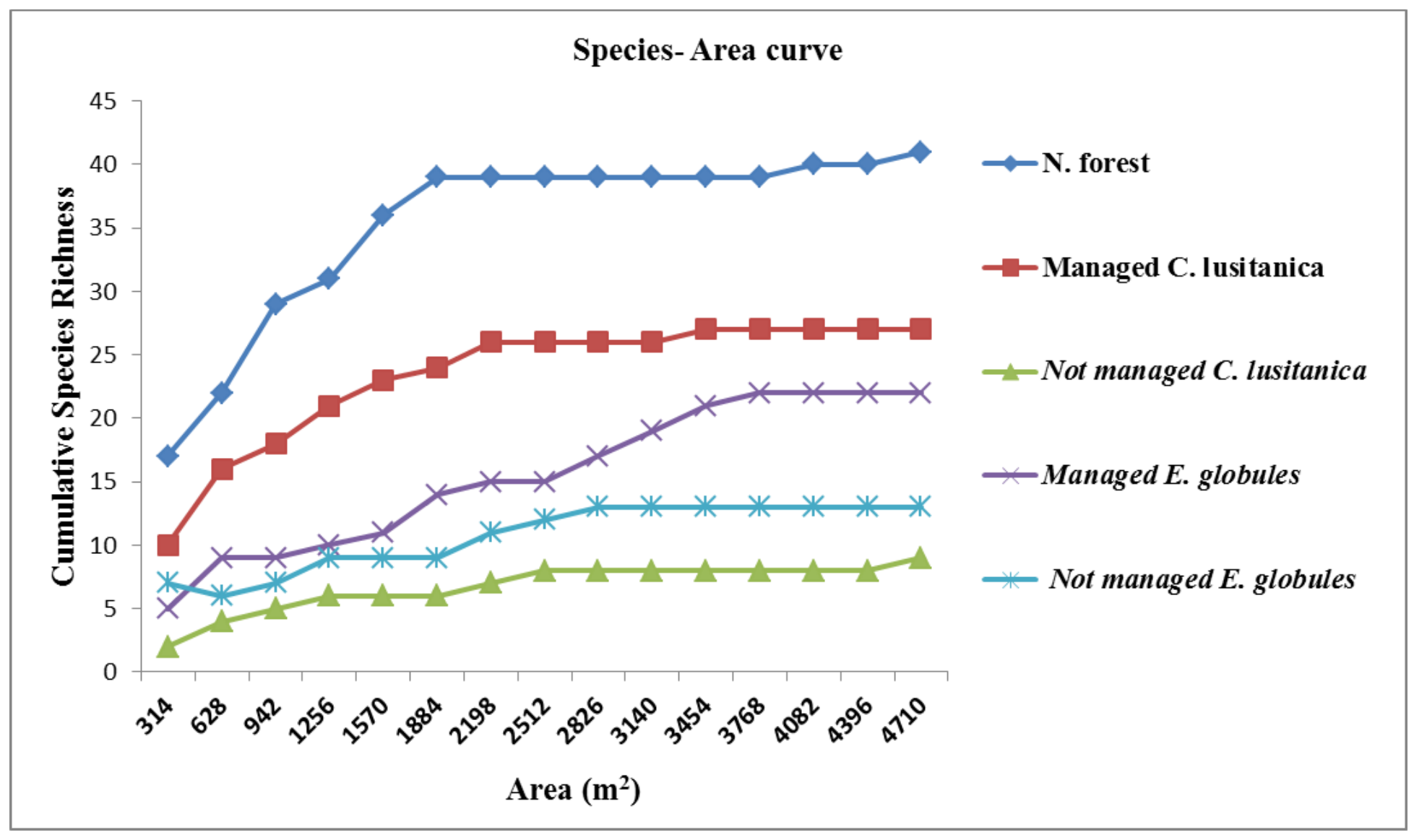

Figure 4

Species-area curve of all species in managed and unmanaged Tarmaber plantation forest and adjacent natural forest. 


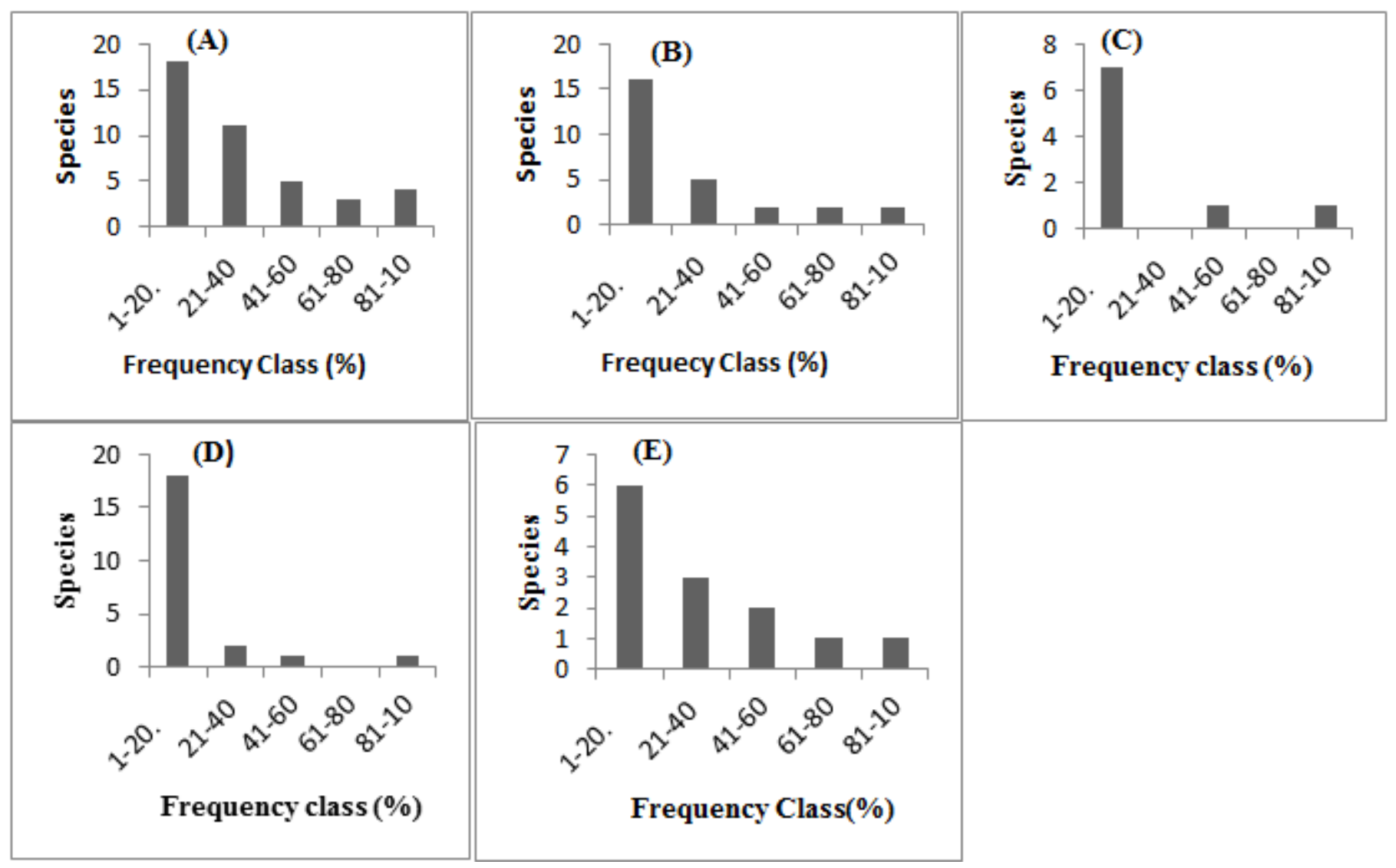

Figure 5

Frequency diagram of woody species in managed and unmanaged plantation forest and adjacent natural forests. A (natural forest), B (Managed C. Lusitanica), C (Not managed C. lusitanica), D (Managed E. globulus) and $\mathrm{E}$ (Not managed E. globulus) 


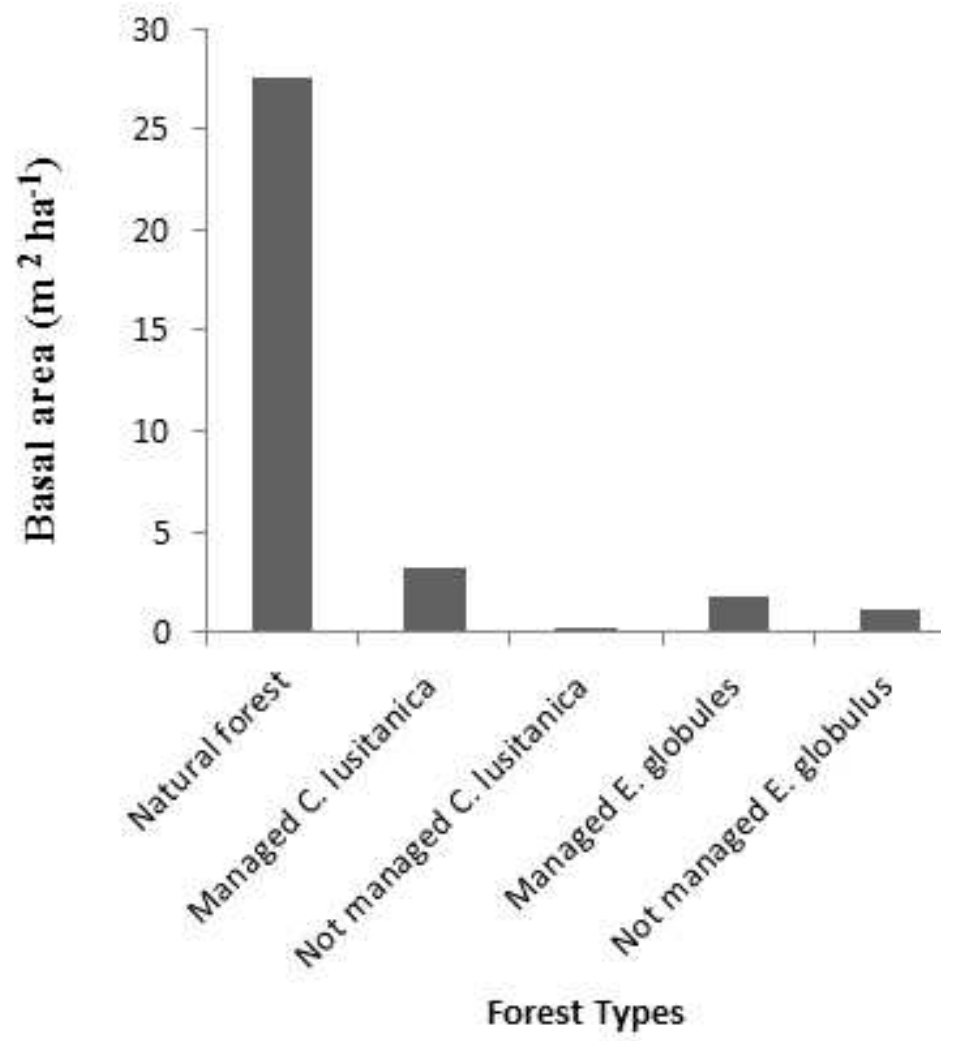

Figure 6

Basal area of plantation forest with and without management intervention and adjacent natural forest

\begin{tabular}{|c|c|c|}
\hline Basal area class $\left(\mathrm{m}^{2} \cdot \mathrm{ha}^{-1}\right)$ & $\left.\begin{array}{l}30 \\
25\end{array}\right]$ (B) & 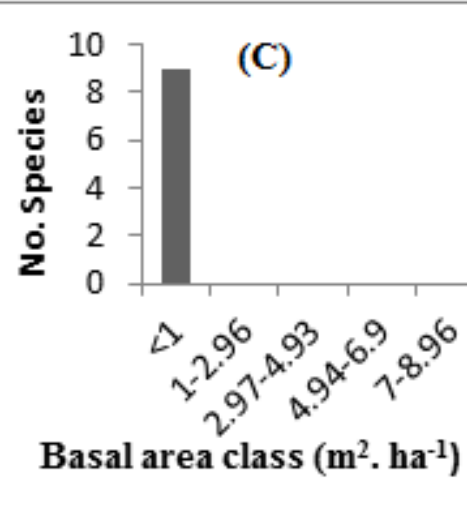 \\
\hline 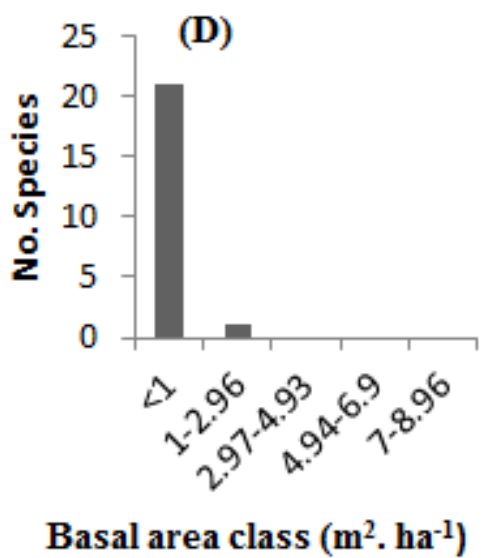 & 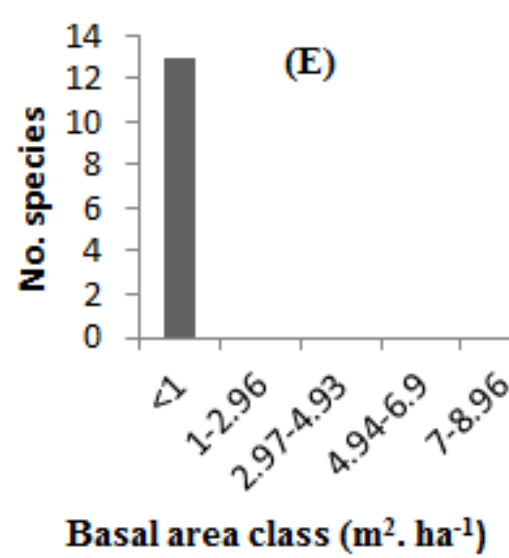 & \\
\hline
\end{tabular}


Figure 7

Number of woody species in different forest types of plantation forest and adjacent natural forests. A (natural forest), B (Managed C. Lusitanica), C (Not managed C. lusitanica), D (Managed E. globulus) and E (Not managed E. globulus)

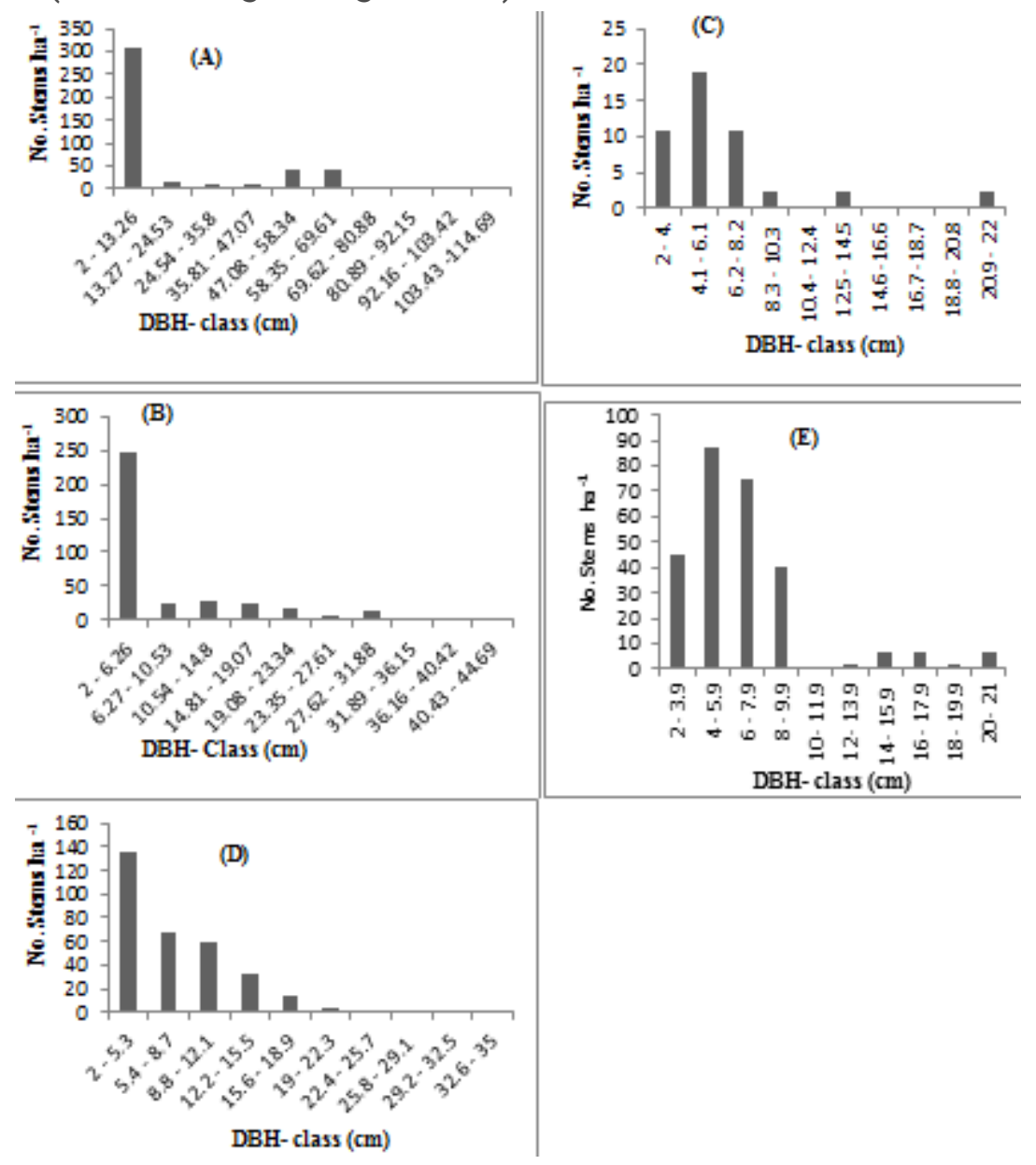

\section{Figure 8}

Diameter frequency distribution of Woody species of in managed and unmanaged plantation forest and adjacent natural forests. A (natural forest), B (Managed C. lusitanica), C (Not managed C. lusitanica), D (Managed E. globulus) and E (Not managed E. globulus), at Tarmaber North Shewa Zone, Ethiopia 

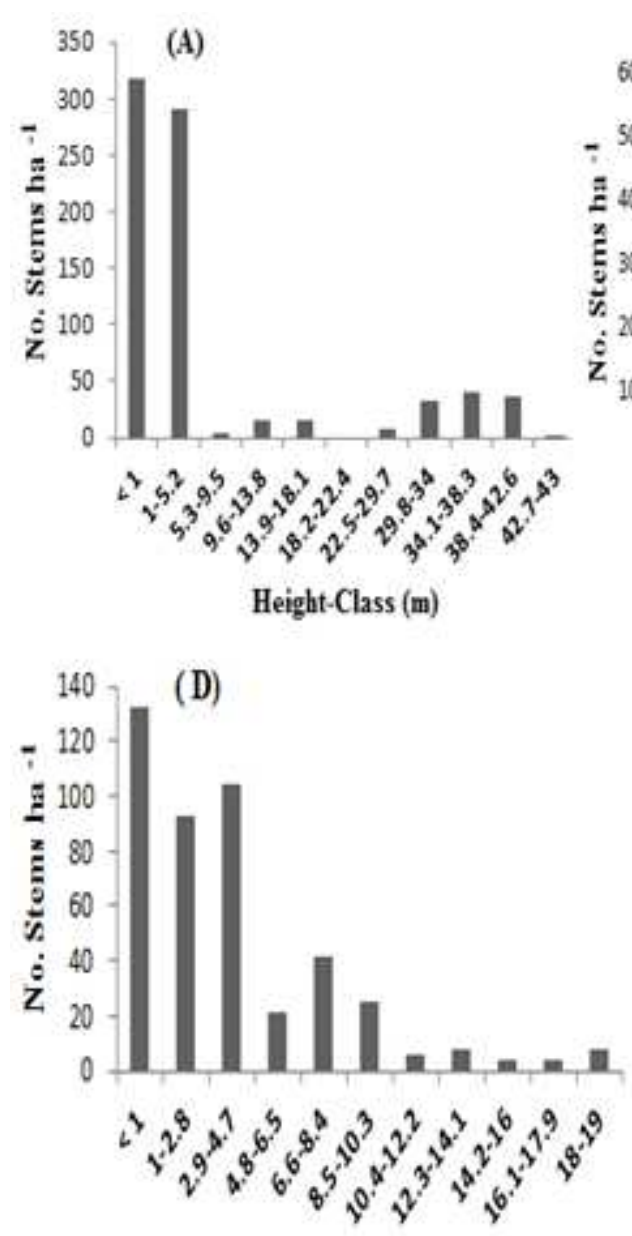

Height-Class (m)

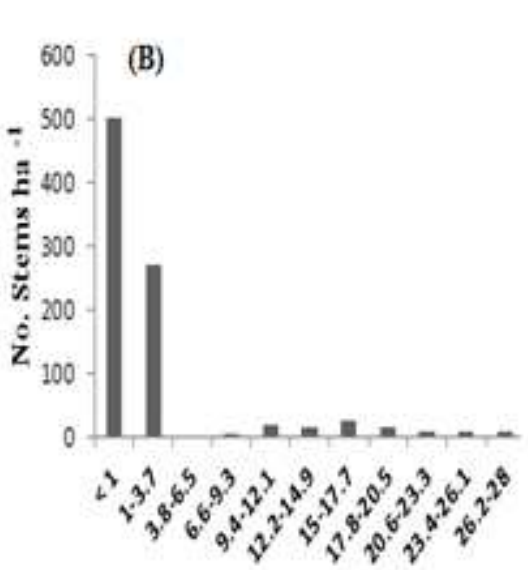

Height-Class (m)

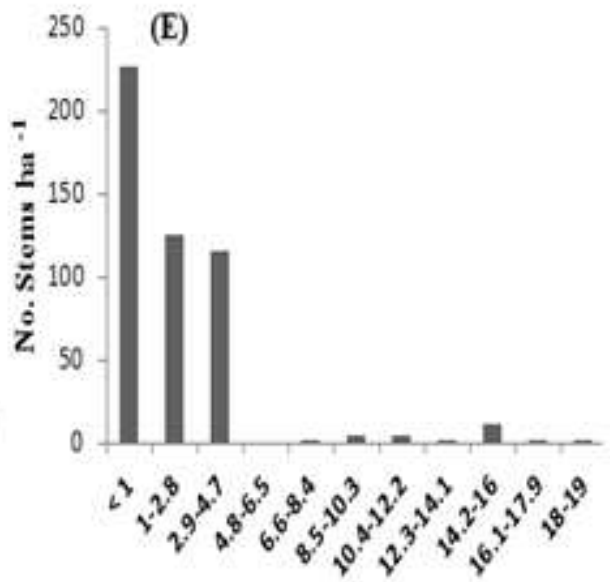

Height-Class (m)

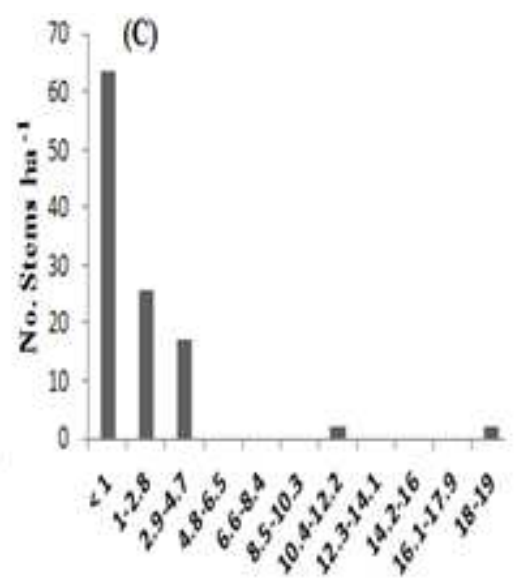

Height-Class (m)

\section{Figure 9}

Height frequency distribution of Woody species in managed and unmanaged plantation forest and adjacent natural forests. A (natural forest), B (Managed C. Lusitanica), C (Not managed C. lusitanica), D (Managed E. globulus) and E (Not managed E. globulus) at Tarmaber North Shewa Zone, Ethiopia

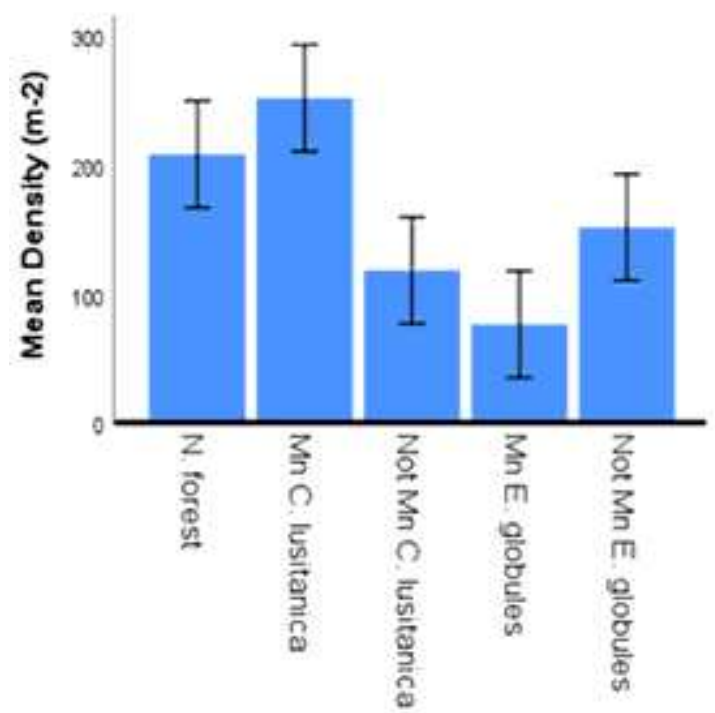

Forest types
N. forest $=$ Natural forest

Mn C. lusitanica $=$ managed C. lusitanica

Not Mn C. lusitanica $=$ Not managed C. lusitanica

$\mathrm{MnE}$. globules $=$ managed E. globules

Not MnE. globules= Not managed E. globules 
Figure 10

Mean density of seeds in the soil seed bank in different forest types from above surface layer to $10 \mathrm{~cm}$ soil depth

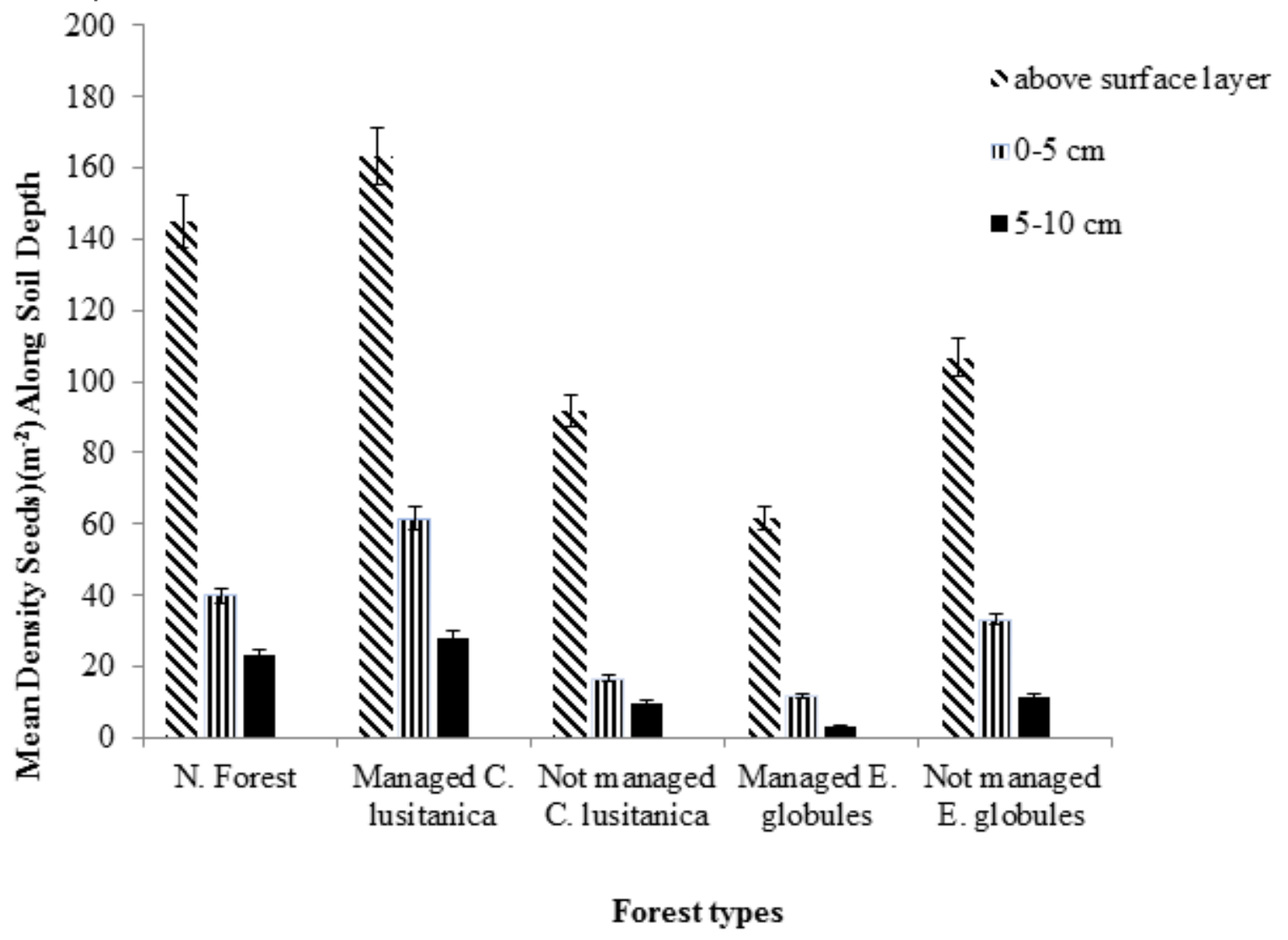

Figure 11

Vertical distribution of viable seeds in soil depth for all forest types 


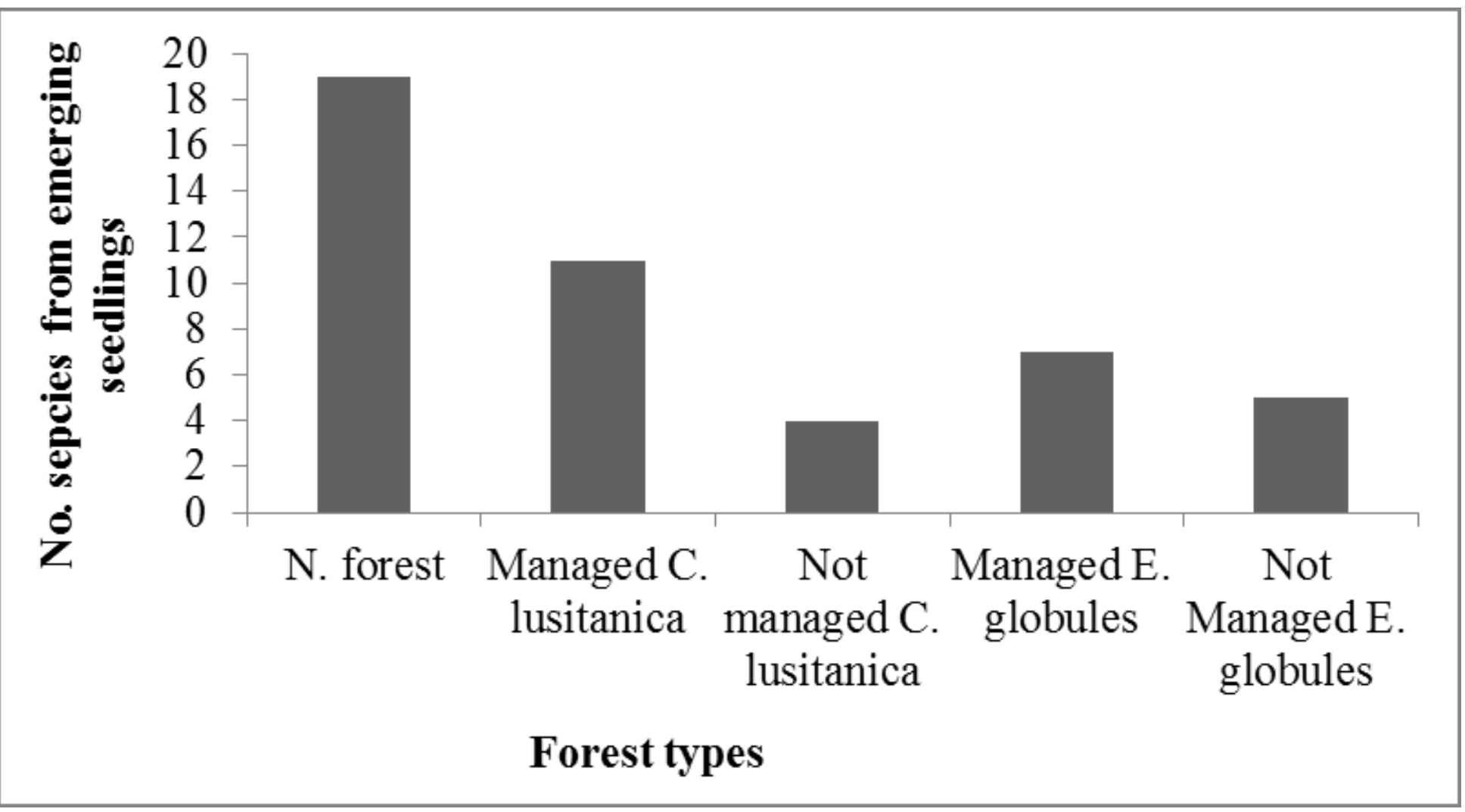

Figure 12

Emergent seedlings number of species in the soils of the different forest types 